\title{
Sartículos
}

\section{La Mariología en el arte mueble medieval en la ciudad de Plasencia}

José Antonio Ramos Rubio

Ayuntamiento de Trujillo (Cáceres)

RESUMEN

La ciudad de Plasencia en Extremadura carece de la infraestructura de investigaciones en el campo medieval que permitan conocer en profundidad su arte y su historia. Ofrecemos el estudio de obras de arte inéditas existentes en las comarcas del Valle del Jerte o de la Vera, y en localidades alejadas del núcleo urbano cabecera de la Diócesis.

PALABRAS CLAVE: Mariología/ Patrimonio Cultural/ Arte Medieval siglos XII-XIV / Cáceres.

Mariology in Medieval Furniture Art in Plasencia.

ABSTRACT

Plasencia's city in Estremadura lacks the infrastructure of investigations(researches) in the medieval field that his(her,your) art and his (her,your) history allow to know in depth. We offer the study of unpublished existing works of art in the regions of the Valley of the Jerte or of the Side, and in localities removed from the urban core (nucleus) head-board of the Diocese.

KEY WORDS: Virgin's Subject/ Cultural Heritage/ Medieval Art XII-XIV ths./ Cáceres.

La ciudad de Plasencia carece de la infraestructura de investigaciones en el campo medieval que permitan conocer en profundidad su arte y su historia ${ }^{1}$. Existe un claro abandono del estudio de obras de arte existentes en localidades alejadas de algunos centros urbanos de importancia. Por supuesto, no hemos de olvidar los estudios sobre el obispado de Plasencia de Fray Alonso Fernández y el del Dr. Luis de Toro, a los que hemos de agregar los episcopologios de los prelados ${ }^{2}$.

\footnotetext{
* RAMOS RUBIO, José Antonio: "La Mariología en el arte mueble medieval en la ciudad de Plasencia", en Boletín de Arte, $\mathrm{n}^{\circ} 29$, Departamento de Historia del Arte, Universidad de Málaga, 2008, págs. 37-67.

1 ANDRÉS ORDAX, S.: "Arte y Urbanismo en Plasencia en la Edad Media". Norba-Arte, VII, Cáceres, 1987, págs. 47-70. RAMOS RUBIO, J. A: Escultura Medieval y Tardomedieval en la Diócesis de Plasencia (Tesis doctoral), Cáceres, 1993. GARCÍA MOGOLLÓN, F. J.: Esculturas de la Virgen María en la provincia de Cáceres. Cáceres, 1987.

2 FERNÁNDEZ, Fr. A.: Historia y Anales de la Ciudad y Obispado de Plasencia. Cáceres, 1627 (reedición, Cáceres, 1952). SAYANS CASTAÑOS, M.: La obra de Luis de Toro. Físico y Médico de Plasencia en el siglo XVI: Descripción de la Ciudad y Obispado de Plasencia. Plasencia, 1961. BENAVIDES CHECA, J.: Prelados placentinos. Notas para sus biografías y para la historia documental de la S. I. Catedral y Ciudad de
} 


\section{Q: artículos José Antonio Ramos Rubio}

Por tanto, nos hemos encontrado con un campo de la Historia del Arte prácticamente virgen, además de no contar los archivos consultados con documentación medieval que permita facilitar la investigación. El ámbito cronológico de este estudio tiene marcado como límite histórico inicial la instauración de la Diócesis de Plasencia a fines del siglo XII (1189). El arte cristiano del momento está marcado por la empresa reconquistadora, enlazando directamente con la construcción de iglesias y la introducción en las mismas del arte mueble, así como la llegada a Plasencia de una abundante imaginería que acompañaba a los ejércitos cristianos en sus campañas militares.

El hecho de ser repoblado el NE. de Extremadura desde Castilla, va a tener sus repercusiones en el terreno de la distribución de las tierras y en la organización religioso-administrativa de las zonas conquistadas, decisión que dará lugar a varias disensiones entre la sede placentina y los Obispados de Ávila y Toledo ${ }^{3}$. El Arzobispo de Toledo intentó hacer valer ante Roma sus derechos sobre la zona, obteniendo una Bula de Honorio III, el 8 de febrero de 1217, para erigir iglesias en diversos lugares de Castilla la Nueva y Extremadura, entre los que se citan varias poblaciones de la Diócesis placentina. A pesar de los intentos, Plasencia conservará su sede episcopal, pasando a ser sufragánea del Arzobispado de Santiago. Finalizo el estudio histórico-artístico en la primera mitad del siglo XVI, con el fin de incluir la imaginería y pintura tardo medieval, es decir, solamente aquellas obras artísticas que aún mantengan algunas características plenamente medievales, debido a la desigualdad existente en el proceso reconquistador de las diferentes localidades pertenecientes a la Diócesis placentina. Nos encontraremos con obras que pueden clasificarse cronológicamente como renacentistas pero que aún presentan formas de tradición gótica. Como bien dice Huizinga en su Otoño de la Edad Media: "Todo el que se propone seriamente establecer una clara división entre la Edad Media y el Renacimiento advierte que los límites se le ensanchan y escapan. Percibe en plena Edad Media formas y movimientos que parecen ostentar ya el sello del Renacimiento, y para poder abarcar también estas manifestaciones se estiran el concepto del Renacimiento hasta un extremo en que pierde toda su fuerza elástica. Pero esto es aplicable también al lado contrario. Quien estudia el espíritu del Renacimiento sin un esquema preconcebido encuentra en él muchas cosas "medievales”, más de las que parecen permitir las teorías“4.

Las manifestaciones marianas muestran como tipificados, unos esquemas devocionales e históricos, que proyectan a su vez manifiestas analogías para la comprensión del fenómeno religioso. Ejemplo de ellos son las relaciones existentes entre

Plasencia. Plasencia, 1907. LÓPEZ SÁNCHEZ-MORA, M. Prelados placentinos. Plasencia, 1977. SÁNCHEZ LORO, D.: Historias placentinas inéditas. Tres tomos, Cáceres, 1982-1985, que recopila y cataloga los numerosos manuscritos inéditos que tratan sobre la historia de Plasencia.

3 FERNÁNDEZ, ALONSO, Fr.: op. cit., t. 1.

4 HUIZINGA, J.: "EI Otoño de la Edad Media", en Revista de Occidente. Madrid, 1967. Cit. por CLARAMUNT, S.: "El arte de la Baja Edad Media Occidental como exponente de una nueva mentalidad". Acta Historica et Archaeologica Mediaevalia, I. Barcelona, Facultad de Geografía e Historia, 1980, pág. 134.

5 BULLÓN DE MENDOZA, A.: Las Órdenes Militares en tierra de Extremadura. Mérida, 1959, pág. 60. 
las imágenes de María y las Ordenes Militares, la principal fuerza cristiana ${ }^{5}$; o el ocultamiento de las mismas con la amenaza musulmana, para aparecerse milagrosamente a los cristianos, persiguiendo claramente con ello la continuidad de un cristianismo hispano-romano ${ }^{6}$.

Son creaciones de un arte, cronológico y espacialmente fronterizo, sin grandes exigencias estéticas como correspondía a la mentalidad de sus devotos: soldados y campesinos, colonos de las feraces tierras de la Extremadura Leonesa. Con ellos llegarían imagineros poco cualificados, prestos a llenar el vacío icónico de su nueva tierra, cuando no traerían sus entrañables imágenes protectoras, rudas como ellos mismos ${ }^{7}$. No obstante, tenemos en la Diócesis placentina obras de notable calidad artística como es el caso de la Virgen del Sagrario de la Catedral de Plasencia, de madera con revestimiento de chapas de plata, culminación de las Vírgenes Madres en Extremadura, es "una de las mejores réplicas de la Virgen de la Sede, de la Catedral de Sevilla"8, reflejando el esquema compositivo que muestran las imágenes de la Virgen en las viñetas de las Cantigas de Alfonso $X^{9}$. Obra fechable en la segunda mitad del siglo XIII.

La más reciente de las provincias eclesiásticas creadas en Extremadura es la Diócesis de Plasencia. Los orígenes y expansión del cristianismo en nuestra región se remontan a principios del siglo $1 \mathrm{II}^{10}$, fecha en la cual quedaría constituida la Provincia Metropolitana de Lusitania, con capital en Augusta Emérita (Mérida), la primera junto con León-Astorga de que se tiene noticia en España ${ }^{11}$. Por tanto, es en Mérida donde se origina y se extiende el cristianismo a toda la actual región extre-

6 MONTES BARDO, J.: Iconografía de Ntra. Sra. de Guadalupe. Sevilla, 1978, pág. 96.

7 Ibídem., pág. 96.

8 SPENCER COOK, W.W. y GUDIOL RICART.: "Pintura e imaginería", en Ars Hispaniae, vol. VI. Madrid, 1950, pág. 389.

9 GUERRERO LOVILLO, J.: Las cántigas. Estudio arqueológico de sus miniaturas. Madrid, 1949, pág. 271.

10 BLÁZQUEZ, A.: "Posible origen africano del cristianismo español", en Archivo Español de Arqueología, XXX-L, Madrid, 1967, pág. 115. Tenemos constancia de la presencia en Lusitania del obispo Marcial (hacia el año 255), en la Sede de Mérida -según el testimonio de la carta de San Cipriano, obispo de Cartago, dirigida a las iglesias de León, Astorga y Mérida- sobre el caso de los obispos libeláticos. CAMACHO MACÍAS, A.: "La sede emeritense y su proyección histórica", Historia de la Baja Extremadura, tomo I, Badajoz, 1986, pág. 233.

11 El documento más antiguo referido a la iglesia emeritense es la Carta 67 del Obispo de Cartago, op. cit. Es anterior al año 258, fecha del martirio de su autor San Cipriano. Vid. CAMACHO MACÍAS, A., op. cit, pág. 233.

A mediados del siglo III tenemos la presencia en Mérida del obispo Marcial, encargado de una comunidad cristiana jerárquicamente organizada (obispo, presbíteros, diáconos) con cementerios y rito funerario propio. SÁNCHEZ SALOR, E.: "Mérida, metrópolis religiosa en época visigótica", Hispania Antiqua, t. V, Valladolid, 1975, págs. 135-150. "Orígenes del cristianismo en Lusitania". Actas Jornadas sobre las Manifestaciones en la Lusitania. Cáceres, 1986, págs. 68-84.

Una fuente importantísima serán las Vitae Patrum Emeritensium (documento anónimo excepcional escrito en Mérida hacia el año 630) según las cuales sus sepulcros eran venerados por el pueblo de Mérida y en ellos se realizaban milagros. GARVIN, J.: The Vitas Sanctorum Patrum Emeretensium. Washington Catholic University of America Press, 1946, pág. 428. Conocemos varias estelas funerarias cristianas de mediados del siglo IV gracias al corpus de VIVES, J.: Inscripciones cristianas de la España romana y visigoda. C.S.I.C. Barcelona, 1969, inscripciones 18 (año 381) y 19 (388). 
meña por medio de sus vías de comunicación.

En 1186, Alfonso VIII declaraba oficialmente la fundación de una gran ciudad $^{12}$, en el rincón sudoccidental del reinado castellano, que habría de ser cabeza de una importante diócesis, a la que dio el nombre de Ambracia, posteriormente mudado por el de Plasencia "ut placeat Deo et hominibus", según palabras del monarca que pasarían después a ser el lema de la ciudad ${ }^{13}$. La fundación de la ciudad se realiza sobre un cerro junto al río Jerte. Al año siguiente, el rey da a Plasencia su Privilegio Fundacional ${ }^{14}$ en donde señala los límites del alfoz placentino ${ }^{15}$ mermando el abulense y el poder de la ciudad sobre él en virtud de la cláusula "ut de eis in eis quidquid voluerint faciant", y en donde aparece el término que dio origen al de la ciudad, "placeat"16. La aparición de los lugares más próximos a Plasencia debió ser correlativa, casi coetánea a la propia Ciudad. Se fueron constituyendo poblados Valle arriba, en el curso ascendente del río Xerit, como Asperilla, Ojalvo, Peñahorcada, Navaconcejo, etc., se irían asentando castellanos en estos núcleos orillados al río. Los montañeses procedentes del reino de León, menos numerosos, se reparten los altos bordes de las dos laderas (Piornal, El Torno, etc...). Los castellanos de la hondonada desarrollaron como actividad primordial la agricultura. Los leoneses se dedicaron al pastoreo. El proceso repoblador no es uniforme en todo el alfoz placentino. Se presenta como irregular, de lenta progresión.

Los términos de la Diócesis por el Sur quedaron ya delimitados en la Bula fundacional: "con Diócesis suficiente erigimos en Iglesia Catedral (la placentina) y con villas, que para su jurisdicción canónica le han sido señaladas; las que se designan en el presente escrito a saber: Trujillo, Medellín, Monsfragorum y Santa Cruz con todas sus pertenencias". Los del Norte se determinan en la Bula de Honorio III, en el año $1218^{17}$, donde a lo señalado se añade la pertenencia de Béjar y su partido con-

\footnotetext{
12 Las razones de la fundación de Plasencia en 1186 son de carácter estratégico, dentro de los planteamientos de la posesión del territorio de esta zona alto extremeña, por la que estaban interesados a fines del siglo XII los almohades y los monarcas cristianos. ANDRÉS ORDAX, S.: op. cit., pág. 48.

13 PALACIOS MARTíN, B.: "Fundación de Plasencia". Plasencia, patrimonio documental y artístico. Plasencia, 1988, pág. 24. Desde luego en el fuero fundacional de Plasencia se dice: "....in loco qui antiquius vocabatur Ambroz urbam edifico"; FERNÁNDEZ, Fr. A. op cit, Libro I, cap. II, pág. 20; BENAVIDES CHECA, J.: El Fuero de Plasencia. Roma, 1896; MAJADA NEILA, J.: Fuero de Plasencia. Salamanca, Librería Cervantes, 1986; RAMÍREZ VAQUERO, E.: El Fuero de Plasencia. ERE, Mérida, 1987; VAQUERO RAMIREZ, M. T.: El Fuero de Plasencia. Mérida, ERE, 1990; Sayans Castaños argumenta arqueológica y epigráficamente la presencia de un poblado celta en la región de "Ambrasco", cuyo centro más destacado era Ambroz; SAYANS CASTAÑOS, M.: Artes y pueblos primitivos de la Alta Extremadura. Plasencia, 1957, págs. 243-260.

14 A. C. P., legajo 29, núm. 14.

15 SANTOS CANALEJO, E. C.: Historia medieval de Plasencia y su entorno geo-histórico: la Sierra de Béjar y la Sierra de Gredos. Cáceres, 1986, pág. 42. Este alfoz se extendía por el sur, atravesando el río Tajo hasta el río Almonte, por el Este y Noroeste, hasta el Tormes, Piedrahita y Garganta de Chilla en el Tiétar, y limitaba con el de Coria por el Oeste. Exceptuamos los castillos de Albalá y Montfragüe.

16 El 4 de diciembre de 1186, Alfonso VIII concede al obispo de Burgos el monasterio de Cervatos a cambio del de Santa Eufemia de Corzuelos, carta hecha en Plasencia: "Facta carta apud Placentiam". Es la primera vez que aparece el nombre de Plasencia en un documento. El rey nos explica el cambio del nombre de "Ambroz" por el de "Plasencia". Manuscrito de Correa y Roldán (escrito en 1579, impreso en 1627).
} 
tra la pretensión del Obispado de Ávila ${ }^{18}$. En la llamada Bula Fundamental, concedida por Inocencio IV, en 1254, se determina lo referente a personal, disciplina, administración de rentas y demás temas relacionados con la Iglesia placentina ${ }^{19}$.

Es evidente, que para el hombre del Medievo la ciencia más importante es la teología, porque lleva a Dios, superando el éxito de la ciencia profana. Los textos sagrados del cristianismo llevaron a una construcción doctrinaria y dogmática en la que la ciencia y el arte presentaron un papel subalterno de servidores; todo hecho, toda historia se remite a una potencia espiritual, la Iglesia ${ }^{20}$.

Tras la tardía reconquista cristiana de los principales centros de población extremeños, se restablece la Iglesia en nuestra región como fuerza ideológica, política y económica. Asistimos desde el siglo XIII a la llegada de comunidades franciscanas $^{21}$, dominicos, etc., que asistían espiritualmente a los ejércitos, impulsando la devoción mariana en numerosas localidades. En su mayoría, son las imágenes denominadas "fernandinas", que acompañaban a los ejércitos en la reconquista, de caracteres iconográficos franceses, lo cual es comprensible, al ser Fernando III, primo hermano de San Luis de Francia, estando desposado el castellano en segundas nupcias con la francesa Juana Ponthieu, y la presencia en Castilla de artistas galos, en busca de trabajo, ante las favorables circunstancias políticas, religiosas y laborales ${ }^{22}$. Responde a estas características artísticas e iconográficas: Ntra. Sra. del Sagrario (Plasencia).

No cabe duda, que en el siglo XIII la idea de María como nueva Eva, no podría tener la difusión que tuvo sin las Cántigas de Santa María del rey Alfonso $X$ el Sabio. Las Cántigas fueron compuestas por Alfonso X, que asimismo mandó ilustrarlas a los miniaturistas de su corte. Los textos loan a la Virgen y narran hechos milagrosos obrados por su intercesión. Se completan con notaciones musicales ya que fueron concebidos para ser musicados. La ilustración de esta obra ofrece una visión muy fresca y directa de la vida cotidiana y de la espiritualidad del siglo XIII.

En la Cantiga núm. 144 se recoge uno de los festejos populares más importantes que tenían lugar en las ciudades, las corridas de toros. La afición festiva más

\footnotetext{
17 Bula del Papa Honorio III por la que confirma al obispo de Plasencia las iglesias del término de Béjar. Roma, 16 de diciembre de 1218.

18 Fueron de Plasencia el Barco de Ávila y Piedrahita. El Pontífice reinante decretó que Béjar y su partido fueran de Plasencia y estas otras localidades de Ávila. El que promovió la primera competencia contra el Obispo de Ávila fue don Domingo (1214-1231), natural de Béjar; la segunda don Adán (1232-1264), a el cual se deben los Estatutos que rigieron muchos años en ella. Guía Eclesiástica del Obispado de Plasencia, Salamanca, abril de 1924, pág. 10.

19 Bula de Inocencio IV, dada en Roma el 10 de mayo de 1254. A. C. P., legajo II, documento 6.

20 SCHLOSSER, J. von: El arte de la Edad Media. Barcelona, 1981, págs. 86 y 87.

21 Ntra. Sra. en Robledillo de Gata (1214) y San Miguel de Plasencia (1233) son los primeros conventos que se fundan en Extremadura. GARCÍA, S. O. F. M.: "Franciscanos". Voz de la Gran Enciclopedia Extremeña, t. V, Mérida, 1991.

22 Ibídem., pág. 7.
} 
arraigada en las localidades de la Diócesis de Plasencia es la taurina. Incluso, a veces, se recurría a corridas de toros para arreglar las iglesias y ermitas ${ }^{23}$. Por ejemplo, numerosas canciones populares del Valle del Jerte y de la Vera se inspiran en temas taurinos y son cantadas en las rondas durante las fiestas patronales. Por lo general, es el hombre el que participa en estos festejos, lo que no impide que las mujeres tengan sus propias corridas. En ocasiones, ambos participan en el festejo. También, se tiene la costumbre del festejo taurino conocido como el toro nupcial, cuando la novia tenía por misión el adorno de los rejones que ponía al morlaco su prometido. La Cantiga núm. 114 de Alfonso X recoge la costumbre de esta corrida en Plasencia. Durante esta corrida placentina asistimos a un milagro de la Virgen ${ }^{24}$. Alfonso $\mathrm{X}$, finaliza la Cantiga con estas hermosas palabras que traducidas del gallego pueden sonar así: "Y de esto hizo una demostración milagrosa Santa María, la Virgen sin par, en Plasencia, tal como yo lo oí contar a hombres buenos y de creer./ Y referían el milagro de esta manera: Que allí vivía un hombre bueno que a esta Señora, tal como yo lo entendí, sabía muy bien agradecerle en todo./ $Y$ a cualquiera que viniese a pedirle algo por ella, en seguida sin engañar lo daba sin retraso ni mentira, porque no quería defraudarla en nada./ Y aunaba en sus vigilias y ni se quedaba sin oír ninguna Hora de su Oficio, porque todo su deseo era agradable (a la Virgen)“ 25.

Algunas de las imágenes marianas tienen desbastada la espalda, para aligerarlas de peso y, por otro lado, era frecuente su vaciado para evitar las grietas de un gran armazón de madera y preservarla de la carcoma. Son conocidas como "vírgenes fernandinas". El rey Fernando III no solo participó del afecto a la Madre de Jesús, sino que fue en él circunstancia fundamental y definitoria. Podemos recoger algunos testimonios consignados por Alfonso X en sus Cántigas. Tal es el caso, de la señalada con el número 221, que menciona la grave enfermedad que en su niñez sufrió, de la que fue curado por la intercesión de la Virgen, dicen así los versos: “... que senpre Deus et ssa Madre/ amou et foi de seu bando/ porque conquereu de mouros/ o mais da Andaluzia"26.

Pero, mucho más explícita en este particular es la Cántiga 292, verdadero panegírico de Fernando III, reconquistador de varias localidades de la Diócesis placentina: "...et sobre tod outra cousa/ assi com`eu d’él oy,/ amaua Santa María/ a tennor que pod’e ual/ Se èl leal contra ela/ foi, tan leal a achou,/ que en todos los seus

23 El Vicario de Cabezuela del Valle solicitó los desembolsos de las corridas para el arreglo de la ermita de Santiago, en cuyo honor se celebró el festejo taurino. A.P.C., Papeles de la ermita de Santiago. V. a. sobre los toros en Plasencia la obra de MATÍAS GIL, A.: Las Siete Centurias de la Ciudad de Alfonso VIII, págs. 259-261. SÁNCHEZ LORO, D.: El parecer de un deán. Cáceres, 1959, págs. 619-622.

24 Cit. ANDRÉS ORDAX, S.: "Arte y Urbanismo en Plasencia en la Edad Media". Norba Arte, VII, Cáceres, 1987, pág. 61. Vid. trabajo de MAJADA NEILA, J.: Dos testimonios sobre Plasencia en las Cantigas de Alfonso $X$ el Sabio. Plasencia, 1972

25 SENDÍN BLÁZQUEZ, J.: Leyendas religiosas de Extremadura. Plasencia, 1989, págs. 194 y 195.

26 Cantigas de Santa María, de Alfonso X. Tomo I, CXII, Madrid, 1989, pág. 318. Cit. HERNÁNDEZ DÍAZ, J.: "Estudio de la iconografía mariana hispalense de la época fernandina". Archivo Hispalense, núms. 27-32, Sevilla, 1948, págs. 10 y 11. 
feitos/ atan ben o aiudou,/ que quanto comenÇar quiso/ et acabar, acabou;/ et se ben obrou por ela,/ benll'ar pagou seu oir/...../ et quand algûa cidade/ de mouros ya ganar,/ ssa omàgen na mezquita/ poye en o portal"27.

El estamento eclesiástico, como principal demandante, encarga obras a artistas de renombre que tienen su taller establecido en los grandes focos artísticos (Salamanca o Toledo ${ }^{28}$. Por tanto, la importancia del arte que se da en los centros rurales de Diócesis placentina viene acrecentada por el hecho de que en ellas se irradian las escuelas artísticas de los grandes núcleos de población.

Las empresas arquitectónicas llevaban aparejadas unas necesidades de tipo escultórico, no solo en la decoración monumental sino en el mobiliario. Los artistas de renombre viajaban de un lugar a otro lugar para realizar los encargos. Estos contrataban los servicios de artesanos locales que tenían la opción de aprender las novedades que ellos traían. Según la General Estoria de Alfonso X, estos entalladores locales se dedicaban a esculpir y vender las imágenes de la Virgen con el $\mathrm{Niño}^{29}$.

\section{VIRGEN CON NIÑO.}

En el Palacio Episcopal, en las dependencias personales del IImo. y Rvdmo. Sr. Obispo, se conserva una imagen de Ntra. Sra. con el $\mathrm{Niño}^{30}$, respondiendo a la representación iconográfica de María como Trono de Dios. Responde al modelo de Virgen Bizantina Teótocos, de la que deriva la Nicopoia o "la que concede la victoria", llamada así porque acompañaba a los ejércitos en las campañas. Es una Virgen Madre (73 x $26 \times 30 \mathrm{cms}$.), en majestad, coronada como reina entronizada; con el Niño Jesús (mide $34 \mathrm{cms}$.), frente al espectador y sobre sus rodillas, bendice con una mano y con la izquierda sostiene el Libro ${ }^{31}$, símbolo de la sabiduría divina de Cristo. Responde a un esquema inspirado en Bizancio, que transportado por comer-

\footnotetext{
27 Ibídem, I, LXXXI, II, 406.

28 Podemos citar el caso de Fernando Gallego, avecindado en Salamanca, que en 1468 aparece trabajando en la Catedral de Plasencia con Jean Felipe; y que es probablemente el autor del retablo de la iglesia de Santa María de Trujillo. Actas Capitulares de la Catedral de Coria, 23 de febrero de 1473. A.C.C. Y en Toledo, a Juan de Borgoña, posible autor del retablo de la ermita de San Lázaro de Plasencia. Vid. ANGULO IÑIGUEZ, D.: Juan de Borgoña. Madrid, 1954, pág. 3. MATEO GÓMEZ, I.: Catálogo. Retablo de la ermita de San Lázaro. Plasencia, 1922.

29 Desde el Concilio de Trullo (695) la Iglesia representaba a Cristo en forma humana y sufriente para hacer frente a las doctrinas monofisitas que querían absorber la naturaleza humana de Cristo en la divina. REAU, L.: Iconografía de lart Chretien, t. II., vol. II., París, Presses Universitaires de la France, 1957, pág. 477. A partir del siglo XIII se representa a Cristo, doliente, pero con gesto amable, quizá como consecuencia de sentimiento religioso expresado por San Anselmo en su Oración ante la Cruz o por San Bernardo. SAN ANSELMO: Obras Completas. B.A.C. Madrid, 1953, pág. 301.

30 Publicada por el autor de esta Tesis. RAMOS RUBIO, J. A.: "Aproximación al estudio de la imaginería mariana del Palacio Episcopal de Plasencia". Alcántara, núm. 20, mayo-agosto, Cáceres, 1990, págs. 111-116.

31 TRENS, M.: op. cit. Como ya hemos visto anteriormente, realiza un pequeño estudio de la significación de algunos atributos que suelen aparecen en las manifestaciones artísticas, como es el caso del libro, símbolo de la sabiduría divina de Cristo.
} 


\section{Q: artículos José Antonio Ramos Rubio}

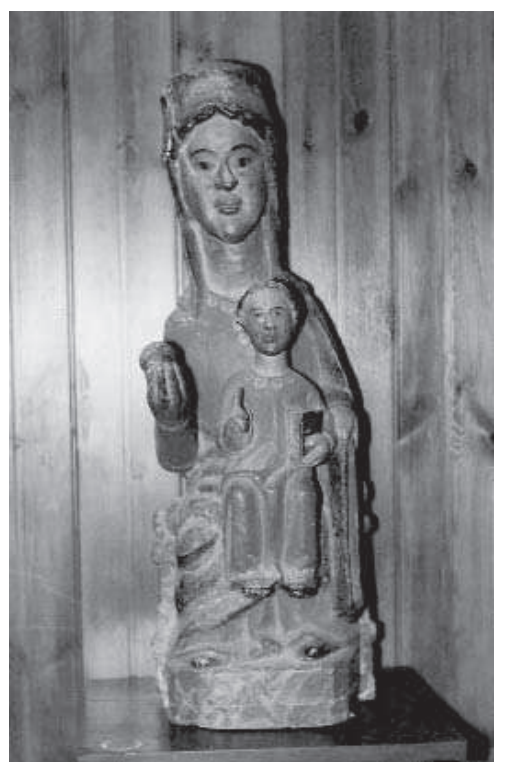

1. Virgen con niño.

ciantes y caballeros cruzados se impone en manuscritos del siglo XI alcanzando una larga pervivencia ${ }^{32}$.

Los pliegues del palio y de la túnica son duros y abstractos, destacando la escasa diferenciación funcional de brazos y piernas, así como el tipo de calzado puntiagudo, características propias del momento; no olvidemos que la escultura románica posee su propio carácter y obedece a sus propias leyes ${ }^{33}$.

La Virgen se nos presenta en actitud sedente sobre un escaño elemental, con molduras en la parte superior, formado por una tabla vertical, sin respaldo. Levanta con su mano izquierda el manto para resguardar lateralmente al Niño, no lo toca directamente como manifestación de su origen divino. Ntra. Sra. lleva en su mano derecha una esfera (manzana), identificándola así con la nueva Eva, que venía a salvar lo que se había perdido a causa de una manzana. A pesar de que claramente se observa la postura frontal y asimétrica del conjunto, se percibe igualmente una cierta sensación de vida, que se desprende de la dulce expresión del rostro de la Virgen y del Niño.

El conjunto está realizado en madera policromada, conservándose la policromía primitiva. Se observa cómo la Virgen es una talla hueca por detrás, lo cual es propio de estas vírgenes conocidas como fernandinas que acompañaban a los ejércitos

32 SANCHO DE SOPRANIS, H.: Mariología medieval xericiense. Jerez, Ed. de Ruiz Lagos, Centro de Estudios Históricos Jerezanos, 1973. LUIS VALDEAVELLANO, G.: "Curso de Historia de las Instituciones Españolas. De los orígenes al final de la Edad Media". Revista de Occidente. Madrid, 1975.

33 FOCILLÓN, H.: La escultura románica. Madrid, Akal, 1987, pág. 15. 
en campaña, como ya hemos estudiado, y como ponen de manifiesto las Cántigas de Alfonso $X$. En algún taller local se incorporó el tablero trasero y se imitó la policromía primitiva a base de roleos enlazados de un cierto sabor gotizante. Un dato importante para fechar la talla es la disposición ajustada del escote del cuello de la túnica de la Madre e Hijo, decorada a base de una bordura de flores de tres pétalos; este tipo de flores aparecen en las orlas que rodean las viñetas de las Cántigas de Alfonso $X^{34}$. La forma ajustada del escote y la pequeña abertura vertical de las dos túnicas eran frecuentes en los trajes lujosos del siglo XIII. Aún, se siguió utilizando este tipo de indumentaria en el siglo XIV, abandonándose poco después ${ }^{35}$.

Por las diversas características expresadas, a las que tenemos que sumar el tipo de corona rústica que porta la Virgen, podemos fechar la obra a mediados del siglo XIII. Según nos han informado, dicha imagen procede de la localidad de Segura de Toro, llegó a Plasencia con el Ilmo. y Rvdmo. Sr. Obispo D. Pedro Zarranz y Pueyo, en 1945. El Obispo sucesor del citado, D. Antonio Villaplana Molina (19761989), trasladó la imagen de la Catedral de Plasencia, donde había estado expuesta en una capilla lateral, hasta su capilla en el Palacio Episcopal, donde actualmente recibe culto.

\section{NTRA. SRA. Del Sagrario.}

Esta imagen es muy venerada por los placentinos, se encuentra presidiendo el tabernáculo del retablo mayor ${ }^{36}$ de la Catedral de Plasencia ${ }^{37}$. Esta imagen, de todas las estudiadas, es la que mejor refleja el esquema compositivo que muestran las imágenes de la Señora en las viñetas de las Cántigas del Rey Sabio ${ }^{38}$.

La imagen es de madera y se representa a la Virgen $(64 \times 17 \times 41 \mathrm{cms})$ sedente sobre un sencillo escaño, sosteniendo sobre la pierna izquierda al Niño (34 cms.), mientras que tiene la derecha vacía, posiblemente, llevaba una fruta esférica. El Niño sujeta con la mano izquierda la esfera del universo, símbolo del poder divino, y bendice con la diestra. La cabeza, el cuello y las manos de Madre e Hijo son

\footnotetext{
34 DELCLAUX, F.: Imágenes de la Virgen en los códices medievales de España. Publicación del Patronato Nacional de Museos. Madrid, 1973.

35 BERNIS, C.: "La moda en las imágenes góticas de la Virgen. Claves para su fechación". Archivo Español de Arte, XLIII, núm. 170, Madrid, 1970, pág. 207.

36 Magnífica obra de la primera mitad del siglo XVII, ejecutada por Gregorio Fernández y los ensambladores vallisoletanos Juan y Cristóbal Velázquez bajo las trazas de Alonso Balbás, ilustrada con lienzos de Rizzi (Leg. 91, 11. Arch. Cat. Plasencia). Vid. MARTín GONZALEZ, J.J.: "Nuevas noticias sobre el retablo mayor de la Catedral de Plasencia (Cáceres)“. Boletín de la Sociedad Arqueológica, XL-XLI, Valladolid, 1975, pág. 300.

37 Cit. MÉLIDA, J. R.: Catálogo Monumental de España. Provincia de Cáceres, t. II, op. cit., pág. 298. Se confunde al decir que es obra de piedra chapeada de plata. Esta imagen estuvo colocada en el altar mayor de la Catedral Vieja y se sacaba en procesión en épocas de sequías. BENAVIDES CHECA, J.: Prelados placentinos... op. cit., pág. 283.

38 GUERRERO LOVILLO, J.: Las Cantigas. Estudio arqueológico de sus miniaturas. Madrid, 1949, págs. 271-282. Cit. MONTES BARDO, J.: op. cit., pág. 102.
} 


\section{Q: artículos José Antonio Ramos Rubio}

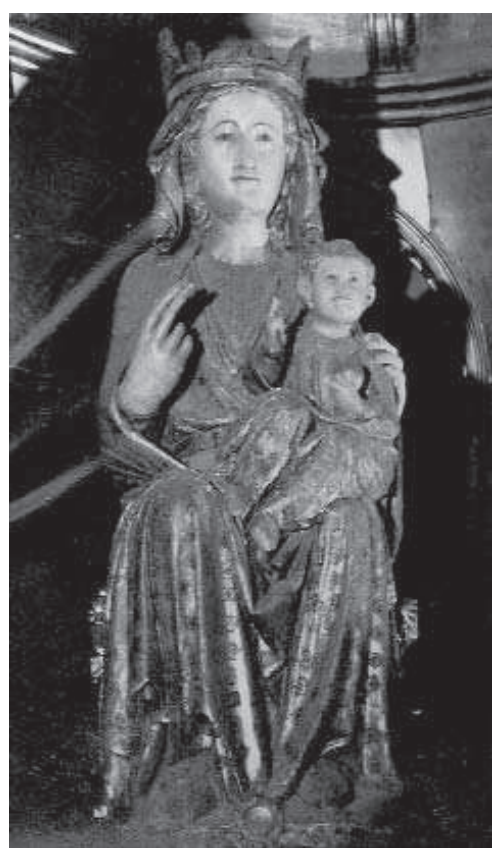

2. Ntra. Sra. del Sagrario.

de madera policromada, el resto de los cuerpos van recubiertos por un chapeado de plata, aplicaciones de plata sobredorada que ofrecen reiteración sistemática de leones y castillos, así como otro signo que pudiera referirse a Plasencia, además de distintos círculos y rombos que contienen rosáceas ${ }^{39}$. Estas referencias heráldicas nos inducen a pensar en la posibilidad de que esta imagen fuera una donación regia a la Catedral de Plasencia ${ }^{40}$. La actitud frontal, corona y trono, son los tres elementos de su soberanía. El elemental escaño, en el cual está sentada la Virgen del Sagrario, así como el resto de imágenes de Ntra. Sra., responden a esquemas repetitivos. El trono admite toda una teoría simbólica, desde las pinturas de las catacumbas, mediado el siglo IV, hasta su dependencia simbólica y formal de la Majestad Domini ${ }^{41}$. Los pliegues del manto y de la túnica son muy realistas, lejos de los duros plegados del

39 Imagen estudiada por ANDRÉS ORDAX, S. y GARCÍA MOGOLLÓN, F. J.: La platería de la Catedral de Plasencia. Cáceres, 1983, págs. 239-245. Los castillos y leones son idénticos a los que se observan en las orlas de las Cantigas de Alfonso X. El castillo de tres torres, es emblema del reino de Castilla; el león rampante, corresponde al reino de León; y un edificio de dos pisos, alude probablemente a Plasencia.

40 Durán Sampere y Ainaud de Lasarte, han señalado su influjo leonés. Por otro lado, Spencer Cook y Gudiol Ricart opinan que esta imagen está muy vinculada con la Virgen de la Sede sevillana, y consideran que ambas tienen origen vasco-navarro. DURAN SANPERE, A. y AINAUD DE LASARTE: "Escultura gótica", Ars Hispaniae, vol. VIII, Madrid, 1956, pág. 134, fig. 122. SPENCER COOK, W.W., y GUDIOL RICART: op. cit., pág. 352. 
románico ${ }^{42}$. Calza la Virgen sus pies con los típicos zapatos puntiagudos, cubiertos por una rica chapa, con aplicaciones doradas geométricas. El Niño viste túnica y manto, cuyos ribetes presentan decoración naturalista gótica constituida por flores de seis pétalos, y lleva los pies descalzos. Es conocido en el período medieval el criterio de revestir de plata a las imágenes que eran muy veneradas, encarnando rostro y manos para darles mayor vivacidad ${ }^{43}$. Estas imágenes de madera chapeada en metales preciosos, tienen una larga tradición francesa que se introduce en la Península por la vía de las peregrinaciones.

La Virgen lleva una corona de madera ${ }^{44}$, constituida por unos florones, y el velo de la sabiduría que deja entrever sus dorados cabellos. La Virgen es una escultura de gran belleza y está ahuecada por la espalda, lo cual es propio de las imágenes fernandinas que acompañaban a los ejércitos en campaña, por eso se las aligeraba de peso, como ponen de manifiesto las Cántigas de Alfonso $X^{45}$. También, para evitar el agrietamiento de la madera por el excesivo peso.

La actitud de las dos efigies es indicativa del abandono del hieratismo románico, en beneficio de un mayor naturalismo, propio del gótico, que se hace patente en los rostros agradables, la disposición de María al sujetar delicadamente al Niño por el hombro izquierdo, y el ligero desplazamiento de las piernas del Niño hacia el regazo de su Madre y el giro de su cabeza hacia el espectador.

Obra del tercer cuarto del siglo XIII, que según el prof. Andrés Ordax, su referencia tipológica más interesante la encontramos en la Virgen de la Esclavitud de la Catedral Vieja de Vitoria ${ }^{46}$. Fue deplorable la actuación en el año 1892 de don Gregorio de la Concha, arcediano de esta Catedral, que ordenó limpiar con agua caliente y jabón el rostro de la Virgen y del Niño, y con tanta fuerza frotaron, que desapareció la patina de fineza exquisita de ambas efigies ${ }^{47}$. La talla figuró en la Exposición de Barcelona de $1929^{48}$, y en la Muestra de Historia y Arte en Extremadura de Cáceres del año $1984^{49}$.

41 Vid. MONTES BARDO, J.: op. cit., pág. 122.

42 La cinta que rodea el escote de la túnica y baja en vertical por el cuerpo de Ntra. Sra. era frecuente encontrarla en las vestiduras lujosas del siglo XIII. Este motivo se llamaba "orfrés", además, el escote en pico de la túnica de María ostenta roleos gotizantes flanqueados por los sogueados de raigambre gótica, y es el resultado de la llamada capa con cuerda habitual en la indumentaria del siglo XIII. GARCÍA MOGOLLÓN, F. J.: op. cit., pág. 123.

43 Podemos citar la Virgen de la Sede (Catedral de Sevilla), la Vírgenes del Sagrario (Catedral de Toledo), la Virgen del Sagrario (de Irache), la de la Vega (Salamanca) y la de Roncesvalles, entre otras.

44 Existen noticias documentales de que en el 26 de agosto del año 1650 el racionero Pedro Simón ofreció 50 reales de a ocho de plata para dorar las coronas de la Virgen y del Niño. La corona del Niño no se conserva y Ntra. Sra. ha perdido el plateado, su corona actual es de madera. Cit. BENAVIDES CHECA, J.: op. cit., pág. 283. 45 ANDRÉS ORDAX, S., y GARCÍA MOGOLLÓN, F. J.: op. cit., pág. 229.

46 ANDRÉS ORDAX, S.: "Arte y Urbanismo de Plasencia en la Edad Media”, op. cit., pág. 69.

47 BENAVIDES CHECA, J.: op. cit., pág. 26.

48 GÓMEZ MORENO, M.: Exposición Internacional de Barcelona, 1929. El Arte en España. Guía del Museo del Palacio Nacional. $3^{\text {a }}$ ed. Barcelona, 1929, pág. 229.

49 LOZANO BARTOLOZZI, Ma M., y SÁNCHEZ LOMBA, F. M.: Catálogo de la Muestra de Historia y Arte en Extremadura. Plasencia, Imprenta "La Victoria", 1984, pág. 107. 


\section{2: artículos José Antonio Ramos Rubio}

\section{Ntra. Sra. del Perdón.}

En la Sala Capitular de la Catedral placentina, conocida también como Capilla de San Pablo, se encuentra una magnífica talla de Ntra. Sra. con el Niño ${ }^{50}$, bajo la advocación de Ntra. Sra. del Perdón ${ }^{51}$. El primitivo lugar en el que estuvo colocada esta imagen fue en una capilla en el presbiterio de la Catedral Vieja, en donde gozó siempre de gran veneración ${ }^{52}$. Esta capilla de Ntra. Sra. se derribó con las obras de la nueva fábrica iniciadas en el año 1497, la imagen fue trasladada al testero de la nave de la Epístola, dentro de la Catedral Vieja ${ }^{53}$. La impresión que da es que pudiera corresponder, junto con la Virgen Blanca, a sendos parteluces del templo original, quizás de las portadas de un crucero desaparecido ${ }^{54}$. Es una imagen de suma importancia artística, tiene unas considerables dimensiones $(120 \mathrm{cms}$.). Es obra de granito policromado, respondiendo al tipo de Virgen "Odegetria" bizantina, elevada sobre un pedestal decorado con motivos vegetales goticistas. Esta magnífica imagen fue exhibida en la Exposición Internacional de Barcelona en el año $1929^{55}$, junto con la Virgen del Sagrario de la misma Seo placentina.

La Virgen María sostiene fuertemente con su brazo izquierdo al Niño, a la vez que le ofrece la fruta esférica con la diestra, representando a María como nueva Eva, salvadora de la humanidad. Lleva una corona, expresión clara de realeza, y se toca con el velo de la sabiduría. El rostro ovalado, presenta gran belleza, está enmarcado por ondulados cabellos que caen sobre los hombros y espalda. Viste túnica de color jacinto, con escote redondo y con pico en el centro que es el cordón, grueso de la típica capa con cuerda que servía para sujetar esta prenda, muy ajustado al cuello ${ }^{56}$. Posee manto de color verde decorado con motivos geométricos y vegetales, con

50 Aparece atestiguada en un documento testamentario del 11 de julio de 1294, que prueba su antigüedad. BENAVIDES CHECA, J.: op. cit., pág. 9.

51 Cit. por MÉLIDA ALINARI, que la fecha a finales del siglo XIII. Catálogo Monumental de España. Provincia de Cáceres, op. cit., pág. 299.

52 En las Actas Capitulares del 14 de diciembre de 1473, se enumeran varias capillas de la Catedral Vieja, entre las que aparece la capilla de Santa María del Perdón. Cit. LÓPEZ SÁNCHEZ-MORA, M.: Las Catedrales de Plasencia. Guía Histórico-Artística. $2^{a}$ ed. Plasencia, 1976, pág. 108. Delante del altar de Ntra. Sra. del Perdón, se enterraron varios prelados placentinos, como es el caso de don Nicolás Bermúdez (1357-1370?), cuyo sepulcro con la escultura del finado estudiaremos más adelante. También, nos proporciona otra noticia sobre la capilla, el martes 12 de junio de 1408, se cantó un responso sobre la sepultura de don Miguel Sánchez, Arcediano (falleció en 1395) y la Misa al Alba fue cantada en el altar de Ntra. Sra. del Perdón Cit. BENAVIDES CHECA: op. cit., págs.11 y 25.

53 LÓPEZ SÁNCHEZ-MORA: op. cit., pág. 109

54 Dado el estado de insuficiente estudio del templo nada podemos indicar pues las noticias de la historiografía artística no tienen adecuada garantía documental. ANDRÉS ORDAX, S.: "Arte y Urbanismo de Plasencia en la Edad Media", op. cit., pág. 69.

55 Manuel Gómez Moreno, en la redacción de la ficha del catálogo de la exposición, escribió lo siguiente: "Virgen de piedra policromada, que llaman del Perdón: siglo XIV y estofada en el siglo XVI. Altura 2'15 mts. Catedral de Plasencia". Exposición Internacional de Barcelona, 1929. El Arte en España. Guía del Museo del Palacio Nacional. $3^{\mathrm{a}}$ ed. revisada por Manuel Gómez Moreno. Barcelona, 1929, pág. 229, ficha núm. 687.

56 BERNIS, C.: op. cit., pág. 208. Los orígenes de esta indumentaria hay que buscarlos en los trajes germanos de fines del siglo XII y los ejemplos españoles más antiguos datan de finales del siglo XIII. En la centuria 


\section{Q: artículos La Mariología en el arte medieval...}

3. Ntra. Sra. del Perdón.

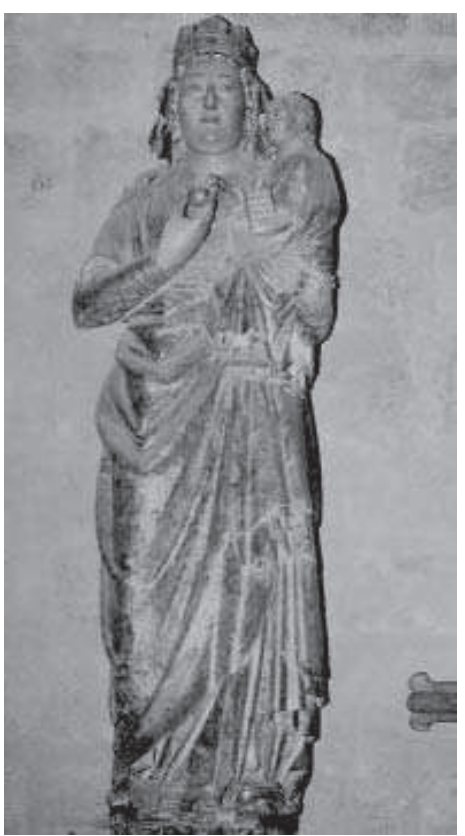

abundantes pliegues que caen paralelos, dejándonos ver los zapatos puntiagudos de Ntra. Sra., rasgo de antigüedad. Curiosamente, presenta anillos en sus manos, embelleciendo aún más esta jerárquica efigie pétrea. Que a pesar del material utilizado, el anónimo artista ha sabido cincelar con maestría.

El Niño viste túnica de color jacinto abrochada con ocho botones dispuestos en dos filas de cuatro cada una y manto verdoso, lleva los pies descalzos, y sostiene el libro de la Sabiduría divina en la mano izquierda. Está completamente desplazado hacia su lado derecho, para poder coger la fruta que su Madre le entrega, lo cual es un rasgo naturalista, típico del arte protogótico de fines del siglo XIII. La policromía no es la original, se le añadió en el siglo XVIII ${ }^{57}$. Es muy parecida a la imagen de Ntra. Sra. la Mayor de la Catedral de Ávila, fechable por Sanpere y Ainaud de Lasarte a fines del siglo XIII ${ }^{58}$. Por todas estas características podemos fechar a la imagen de Ntra. Sra. del Perdón en el último tercio del siglo XIII.

siguiente continúa esta tradición, pero los cordones son más finos. La utilización de botones en el "orfrés" del Niño nos lleva a finales del siglo XIII, elementos que se emplean en las viñetas de las Cantigas y de la General Estoria de Alfonso X. Cit. GARCÍA MOGOLLÓN, F. J.: Imágenes de la Virgen María en la prov. de Cáceres, op. cit., pág. 130.

57 BENAVIDES CHECA: op. cit., pág. 314., nos informa que el 22 de octubre del año 1744, el Cabildo concedió licencia para que un artista "pintase, retocase y barnizara de nuevo la imagen de Nuestra Señora del Perdón". 


\section{Q: artículos José Antonio Ramos Rubio}

\section{NTRA. SRA. con EL NiÑO.}

En una capilla del lado de la Epístola de la iglesia parroquial de San Nicolás, se conserva una imagen en piedra granítica policromada de Ntra. Sra. $(112$ × 37 × 28 cms.) con el Niño (41 cms.). Obra de fines del siglo XIII. No es originaria de esta iglesia, perteneció a la ermita de Fuentidueñas, cerca de Plasencia. Fue trasladada a esta parroquia en el año $1969^{59}$. Según Díaz Coronado, "esta ermita de Fuentidueñas, perteneció a un convento de Templarios. Esto se afirmó en el Concilio que por mandato de Clemente $V$ se celebró en Salamanca en 1310, y al que asistió el noveno obispo de Plasencia don Domingo II"60. Esta ermita, convertida actualmente en edificio al servicio de la explotación agrícola, conserva sus muros maestros.

Se nos ofrece esta imagen de Ntra. Sra. con el Niño a la manera de una "Odegetria" bizantina, su cuerpo se encorva con suavidad hacia su derecha, característico ritmo praxitélico propio de la escultura gótica de fines del XIII y principios de la siguiente centuria. Sujeta al Niño con su brazo izquierdo. Ntra. Sra. deja entrever la típica sonrisa arcaica. Ntra. Sra. dirige su mirada hacia el fiel devoto, mientras que el Niño, de perfil, mira hacia su Madre a la cual acaricia con su mano derecha, mientras que con la izquierda toma la fruta esférica que María le entrega. Cubre su cabeza con un velo largo y se toca con una sencilla corona, dejando al descubierto sus cabellos ondulantes en larga melena. No conserva la policromía original, ha sufrido múltiples repintes.

En la actualidad se encuentra en lamentable estado de conservación. Viste túnica de color blanco, sujeta por un cinturón que aprieta el talle a buena altura, y manto azulado con los bordes dorados, dejando ver los zapatos puntiagudos con los que calza sus pies la Virgen. Los pliegues de la túnica son pesados, geométricos y paralelos, pero los del manto, forman algunos repliegues interesantes y elegantes, imprimiendo a la imagen un cierto encanto artístico, a pesar de la dureza del material escogido. El Niño viste túnica talar de color azulado, con los ribetes de las bocamangas dorados. Otro rasgo importante, que nos permite fechar esta imagen, nos lo indican los escotes despegados de la base del cuello, y el cinturón muy alto con el cual la Virgen se ciñe la túnica al cuerpo. Por los detalles expresados, podemos fechar esta imagen en los años finales del siglo XIII.

58 También, la imagen de Plasencia mereció la atención de Agustín Durán y Juan Ainaud: "La Virgen del Perdón es una labra de piedra policromada, resuelta con sentimiento formal evidente,..". DURAN SANPERE, A. y AINAUD DE LASARTE: op. cit., págs. 134 y fig. 121; 93 y fig. 81.

59 Agradecemos al sacerdote don Francisco Clemente Serrano esta detallada noticia. Además, en el testamento de don Diego de Xerez, consejero de los RR. Católicos y Deán de la S.I. Catedral placentina, menciona a ermitas de su devoción, y figura la primera la de Fuentidueñas, dejando un real de plata a cada una de ellas (San Cristóbal, San Pablo y Santa María del Puerto). Testamento otorgado el 18 de septiembre de 1509, leg. XIII, núm. 44. Archivo de la Catedral de Plasencia. Podemos conocer datos biográficos interesantes sobre Diego de Xerez en SÁNCHEZ LORO, D.: El parecer de un deán. Cáceres, 1959, pág. 51.

60 DÍAZ CORONADO, J.: Guía histórico-artística y turística de Plasencia. Plasencia, 1949, págs. 62 y 63. 


\section{Q: artículos La Mariología en el arte medieval...}

4. Ntra. Sra. con el Niño.

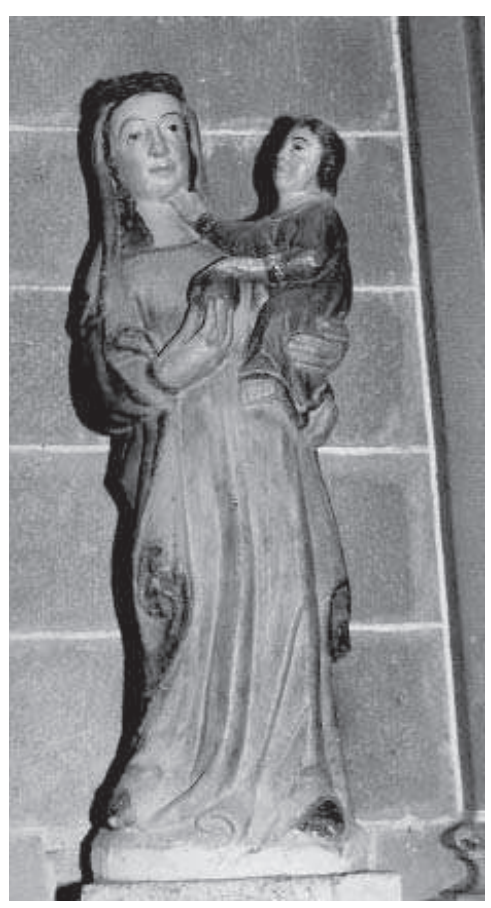

\section{Santa Maria la Blanca.}

En el claustro de la Catedral de Plasencia se encuentra una escultura de granito policromada de Ntra. Sra. (180 x 35 × 26 cms.) con el Niño (44 cms.), bajo la advocación de Santa María la Blanca ${ }^{61}$. Pero, este no es su emplazamiento primitivo. A principios de siglo estaba en la Sala Capitular o capilla de San Pablo, que fue antigua sacristía, en donde la mandó colocar el Deán don Eugenio Escobar ${ }^{62}$. Pero, su emplazamiento habitual, en la que era muy venerada, fue en su propia capilla, junto al sepulcro del reconquistador de Sevilla don Benito ${ }^{63}$. En fecha posterior, don

61 "La advocación de la Virgen Blanca -dice Ángel de Apraiz- es indudablemente una advocación popular cuyos datos más antiguos y foco principal los encuentro en Navarra en el siglo XII. De allí se difunde por los caminos de peregrinación, por las influencias navarras y por efecto de la común sensibilidad de los últimos siglos de la Edad Media, con la ternura humanizada y el refinamiento de la época, en imágenes blancas de rostro y policromadas. A las que por esa condición de tal nombre, que es en sus principios como un adjetivo y un epíteto". APRAIZ, Á. de: "Origen y advocación e imágenes de la Virgen Blanca". Boletín de la Sociedad de Arte y Arqueología, fasc. XL a XLII, t. XII. Valladolid, 1945-1946, pág. 54.

62 MÉLIDA ALINARI, J. R.: op. cit., pág. 299. No obstante, este autor la fecha en el siglo XIII. Posteriormente, veremos por una serie de características que puede corresponder a la siguiente centuria.

63 "En 20 de julio de 1406 otorgó testamento la Sra. Leonor Sánchez, llamada la Ferrusa, viuda primero de 
Enrique de Guzmán ordenó construir un altar en el claustro para rendir allí culto a esta imagen, pero bajo la advocación de Ntra. Sra. de la Encarnación ${ }^{64}$. Según el prof. Andrés Ordax, es probable que "esta imagen, junto con Ntra. Sra. del Perdón, pudieran haber estado situadas en sendos parteluces del templo original, quizás de las portadas de un crucero desaparecido"65. Son varios los autores que en sus obras nos hablan de esta imagen ${ }^{66}$. Siendo muy bien descrita por dos expertos en imaginería gótica como son Agustín Durán y Juan Ainaud: “...cuyo cuerpo de canon muy alto posee esa cualidad imposible de descubrir por el análisis que diferencia una talla vulgar, aunque cuando buena, de una verdadera imagen sagrada; es sin duda una profundidad anímica trasvasada por el escultor a la materia inerte" 67 .

Obra de formas esbeltas, de tipo orientalizante, muy lejos de la alabastrina Virgen Blanca de la catedral de Toledo, en la que nos encontramos con una tierna y risueña imagen de la maternidad, un concepto inocente y arcaico de la escultura. En la efigie de Plasencia, Ntra. Sra. realiza un juego de caderas propio de la escultura gótica más avanzada del siglo XIV. Se nos ofrece María de pie, respondiendo al tipo de una "Odegetria" bizantina, realizando el mismo movimiento hacia su derecha que hemos visto en la imagen de la iglesia de San Nicolás. A su vez, sostiene al Niño con su brazo izquierdo y con la diestra le entrega un ave, aspecto interesante que imprime a la composición un mayor naturalismo, la relación entre Madre e Hijo ${ }^{68}$. Tiene algo desbastada la espalda, para poderla arrimar al muro y para quitar parte de su extrema

Ferrand Alvarez, y después de Alfonso González, se le enterró en la Catedral, delante de la capilla de Sta. María la Blanca, en la sepultura de sus bisabuelos D. Benito y $D^{a}$. Gaxeta, en un sitio que tiene unos leones que está hasta el claustro dentro de la iglesia". BENAVIDES CHECA, J.: op. cit., pág. 10.

64 También, aparece citada en varios documentos del Arch. Catedralicio placentino. En el testamento de don Diego de Xerez, Deán de Plasencia, 18 de septiembre de 1509. En 9 de abril de 1508, en el testamento del Tesorero don Enrique de Guzmán, se dice: "que mi cuerpo sea sepultado en la capilla de la claustra en la que yo hize seyndo Mayordomo (en 1503) de la dicha eglesia donde está la Ymagen de Nuestra Señora". BENAVIDES CHECA, J.: op. cit., págs. 16, 19 y 26.

65 Según ANDRÉS ORDAX, S.: "Arte y Urbanismo de Plasencia en la Edad Media", op. cit., pág. 69. No olvidemos que Benavides Checa nos dice que "cuando terminaron las obras de defensa, la Iglesia Catedral primero, la parroquia de San Pedro en el extremo opuesto, la de San Martín (en las jambas de la puerta de esta iglesia, se lee: "Estos arcos fizo Joan Domingues mayordomo Era MCCXXVIII" (corresponde a 1200), y la Magdalena en lo más apartado de la fortaleza, son los primeros templos que don Bricio consagra al Señor. Así la primitiva Catedral estuvo enclavada en la parte de lo que hoy ocupa la iglesia de Santa Ana. Estos templos corresponden al año 1200. BENAVIDES CHECA, J.: op. cit., pág. 19.

66 WEISE: Spanische Plastik. Gryphius, 1927, pág. 69. DURAN SANPERE, A. y AINAUD DE LASARTE, J.: Escultura gótica. Ars Hispaniae, vol. VIII, Madrid, 1956, pág. 134. LÓPEZ SÁNCHEZ-MORA, M.: Guía Histórico-Artística de Plasencia. Plasencia, 1976 (2 ed.), pág. 102. GARCíA VIDAL, C. (et. al.): Plasencia, Ed. Everest. León, 1982, págs. 78 y 81. GARCÍA MOGOLLÓN, F. J.: Esculturas de la Virgen María en la Provincia de Cáceres, op. cit., pág. 132.

67 DURÁN SANPERE Y AINAUD DE LASARTE, op. cit., pág. 134.

68 El ave en manos de la Virgen y del Niño puede representar el alma del pecador que escapa al lazo de los cazadores que lo persiguen, y encuentra cobijo en manos de María. El Salmo 124-7, nos dice al respecto: "Escapó nuestra alma como avecilla del lazo del cazador; al romperse el lazo, fuímos librados". La paloma, es también, símbolo del E. Santo, y pone de manifiesto -al estar en manos de María y Jesús- el misterio de la Anunciación y de la divina maternidad de María (no olvidemos que durante años se la conocía a la Virgen Blanca, bajo la advocación de la Encarnación). TRENS, M.: op. cit., pág. 547. También, podemos citar la 


\section{Q: artículos La Mariología en el arte medieval...}

5. Santa Maria la Blanca.

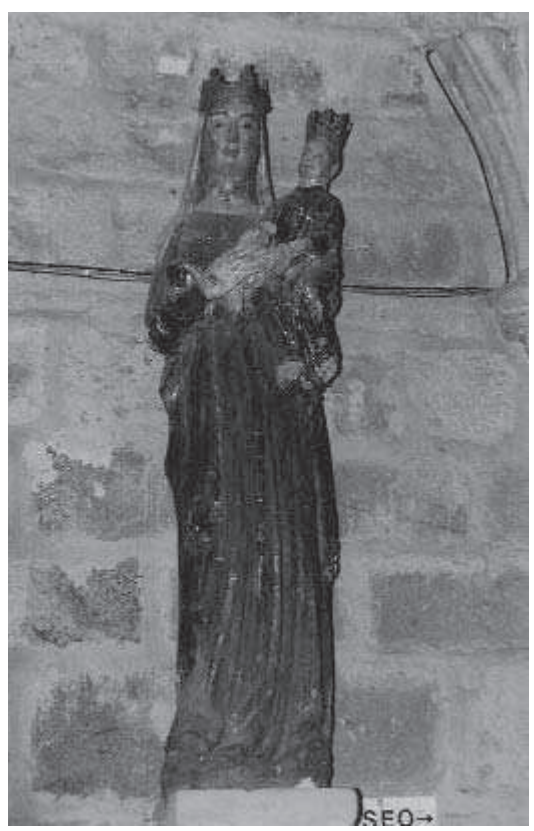

pesadez. Ntra. Sra. cubre su cabeza con un velo de color marfil, simbólico de la sabiduría. Viste túnica rojiza con adornos geométricos, posiblemente añadidos posteriormente al igual que las coronas de Madre e Hijo, sujeta por un cíngulo muy alto, siguiendo la moda característica del siglo XIV. También, de esta centuria es el escote de la túnica de la Virgen, no tan ajustado al cuello ${ }^{69}$. Sobre la túnica, lleva un manto de color azul oscuro, adornado con motivos vegetales y geométricos, que cae con abundantes pliegues pesados y paralelos, dejándonos ver los zapatos de punta redonda. El Niño viste túnica talar (con el escote ajustado al cuello) de color marrón con adornos estofados semejantes a los de su Madre y lleva los pies descalzos. Gran parte de la policromía ha desaparecido, la imagen se encuentra en mal estado de conservación. Por todas estas características, podemos fechar esta obra a principios del siglo XIV, realizada por un escultor castellano anónimo ${ }^{70}$, influido por modelos franceses.

leyenda de las aves de barro que Jesús fabricaba dándolas luego vida, según el relato del Apócrifo del pseudo Mateo. SANTOS OTERO, A.: op. cit., cap. XXVII, pág. 225.

69 BERNIS, C.: La moda y las imágenes góticas de la Virgen, op. cit., pág. 207.

70 Durán Sanpere y Ainaud de Lasarte: Escultura gótica, op. cit., la ponen en contacto con el foco leonés. Figuró en la Exposición: Patrimonio Histórico de Extremadura. Edad Media y Renacimiento, celebrada en Cáceres, en el año 1990. PIZARRO GÓMEZ, F. J. (et. al.): Patrimonio Histórico de Extremadura. La Edad Media y Renacimiento, Catálogo de la Exposición, Mérida, 1990, págs. 46 y 47 


\section{2: artículos José Antonio Ramos Rubio}

\section{VIRGEN DEL BUEN SUCESO.}

En el colegio de RR. MM. Josefinas de la Santísima Trinidad se conserva una escultura en madera policromada de Ntra. Sra. $(57 \times 30 \times 20 \mathrm{cms}$.) con el Niño (23 cms.), bajo la advocación del Buen Suceso ${ }^{71}$. Sin duda, pertenece a otra advocación que la del Buen Suceso. Su denominación le viene con motivo de la fundación del obispo don Pedro González de Acevedo, el cual compra unas casas en la calleja de la Pardala por 700 ducados, en el año 1594, para poder cobijar y adoctrinar en ellas a los niños de la ciudad y la puso bajo la protección de Ntra. Sra. del Buen Suceso, dejándole una renta de 200 ducados $^{72}$. En esta casa, hoy colegio de las Madres Trinitarias, se mantiene la heráldica del Prelado y algunos otros detalles de aquella fundación, en un pequeño museo que las Religiosas han preparado. Procede de la ermita de San Cristóbal, situada en el barrio de San Miguel de Plasencia, desconociéndose el momento exacto en que llegó a este colegio. La Virgen se nos ofrece de pie con corona y cetro de plata (sin marcas) en la mano derecha, sosteniendo al Niño con la mano izquierda. Este sujeta con la mano izquierda la bola del mundo, símbolo del poder divino, y bendice con la diestra. El Niño está desplazado del centro de la composición, en actitud más avanzada anunciando ya el gótico. Responde al tema mariano, muy repetido en el arte bizantino ${ }^{73}$, de Virgen Odegetria o Conductora. Ntra. Sra. está de pie llevando en el brazo izquierdo a su Hijo, causa de sus prerrogativas.

La túnica de la Virgen es recta, sin pliegues, adornada con motivos vegetales; mientras que la del Niño está plegada, esto nos induce a pensar que probablemente fuera una imagen de vestir. Todas estas características nos inducen a datar la obra en la primera mitad del siglo XIV.

\section{NTRA. SRA. DEL SOCORRo.}

Son varias las imágenes que representan a Ntra. Sra. amamantando al Hijo en las localidades de la Diócesis de Plasencia, conocidas con el nombre genérico de Vírgenes de la Leche. En Plasencia existen tres, además de la Patrona de la ciudad, Ntra. Sra. del Puerto, hay una imagen exactamente igual, en la iglesia del Salvador ${ }^{74}$ y, otra más antigua que estas dos efigies, instalada en la hornacina del Cañón o

71 BARRIO RUFO, J. M.: Apuntes para la Historia General de la M. N. y M. L. ciudad de Plasencia. Impr. Manuel Ramos, Plasencia, 1851, pág. 24, nos refiere que esta imagen es una de las más antiguas de Plasencia y la data en el siglo XIV.

72 FERNÁNDEZ, Fr. A.: op. cit., pág. 476. Cit. por V.V. A.A.: Plasencia. Patrimonio Documental y Artístico. Catálogo de la Exposición realizada en los días 17 al 30 de Junio de 1988 en el Complejo Cultural "Santa María" de Plasencia. Inst. Cultural "El Brocense". Plasencia, 1988, pág. 125.

73 Es más, en su afán de investigar agudamente sobre la exactitud de la iconografía mariana, los bizantinos se ufanaban de poseer el autorretrato de la Virgen, venerado en el templo de Ntra. Sra. de Jerusalén, al que llamaban Akeiro poietos (no hecha de manos), es decir, autógrafo de María. Summa Artis, VII, pág. 441. Cit. por HERNÁNDEZ DÍAZ, J.: “Iconografía mariana hispalense”. Archivo Hispalense, núm. 27-32. Sevilla, 1948, pág. 5. 


\section{Q: artículos La Mariología en el arte medieval...}

6. Virgen del Buen Suceso.

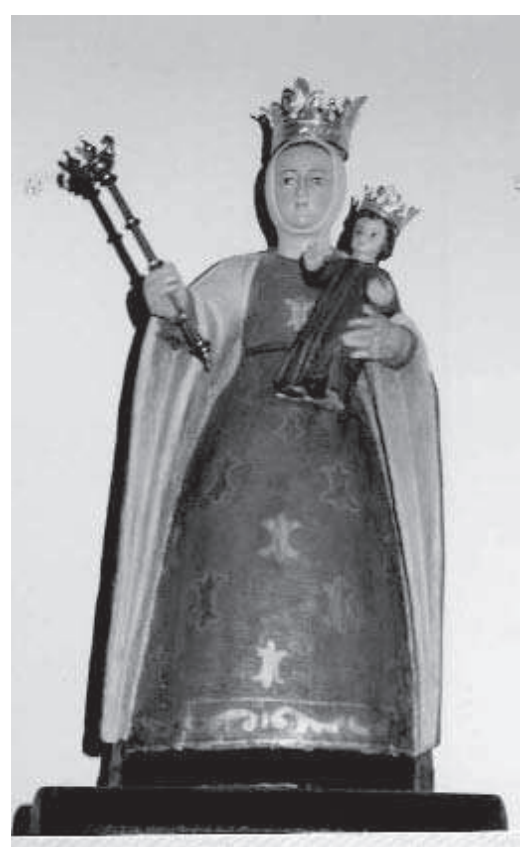

Bóvedas del Marqués de Mirabel con la denominación de Ntra. Sra. del Socorro ${ }^{75}$. Se nos presenta María (73 x 43 × 39 cms.) entronizada, ofreciendo el pecho al Niño que está sentado sobre su rodilla izquierda (36 cms.). Ntra. Sra. cubre su cabeza, coronada, con un velo. El rostro de perfil alargado y suaves facciones, está enmarcado por el cabello, que asoma únicamente en la zona delantera, dejando despejada la frente. Viste túnica larga de color rosáceo y manto azulado, con adornos vegetales, que cae en abundantes y contrastados pliegues verticales que se quiebran abajo, dejando visible la punta del calzado. El Niño viste túnica talar, del mismo color que la de su Madre. Siendo dorados los ribetes de las bocamangas y bordes del manto y túnica, en ambas efigies.

La relación afectiva que se establece entre Madre e Hijo -cruce de miradas,

\footnotetext{
74 Virgen alabastrina, que aún conserva en algunas zonas la policromía original, de la cual ofrecemos la fotografía, que responde al tipo "galactotrofusa" o de la Leche, realizada hacia el año 1500 para el enterramiento de Francisco de Tamayo. En el banco existe la siguiente inscripción: "Este altar y Ntra. Sra. y sepultvra mando zer/ i doto franco de Tamayo". Cit. ANDRÉS ORDAX, S. op cit. pág. 69. También, López SánchezMora nos dice: "en la iglesia del Salvador se da culto a una imagen de la Patrona de la Ciudad, la Stma. Virgen del Puerto, en alabastro, de últimos del XV". LÓPEZ SÁNCHEZ-MORA, M.: Plasencia, guía históricoartística, op. cit., pág. 70

75 En la peana de la imagen se puede leer: "Na Sa del Socorro".
} 


\section{Q: artículos José Antonio Ramos Rubio}

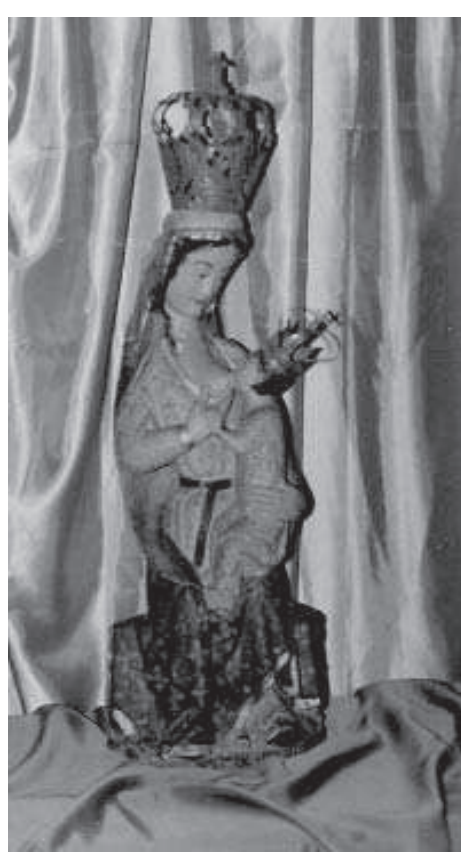

7. Ntra. Sra. del Socorro.

la Madre entrega el pecho al Niño para tomar la leche-, en definitiva un naturalismo y una frescura poco común, en donde se observa el encanto de la expresión maternal y una refinada elegancia; así como los rasgos puramente formales de las figuras, el tratamiento de los pliegues de las indumentarias, el volumen de la imagen, nos invitan a opinar que nos encontramos ante una de las mejores realizaciones góticas existentes en la Diócesis placentina. Es, por tanto, una interesante efigie mariana del tipo "galactotrofusa", que tiene los caracteres propios de la figura maternal de la Virgen de la Leche del siglo $\mathrm{XIV}^{76}$.

\section{Imágenes en la fachada del Perdón (Catedral de Plasencia).}

La fachada de los pies de la catedral de Plasencia, conocida como fachada del Perdón es, posiblemente, el conjunto más antiguo de toda la fábrica eclesial, obra protogótica realizada en tiempos del prelado don Domingo Jiménez ${ }^{77}$. Su construc-

76 Cit. por ANDRÉS ORDAX, S.: op. cit., pág. 69.

77 Esta fachada ha sido descrita por varios autores, pero la fechan en los inicios del siglo XIII y, más bien, es obra del último cuarto del siglo XIII, entre los que podemos destacar a MÉLIDA ALINARI, J. R.: Catálogo Monumental de España. Provincia de Cáceres, op. cit., págs. 273 y 274 . TORRES BALBÁS, L.: "Arquitectura gótica", en Ars Hispaniae, vol. VII, Madrid, 1952, pág. 160. 
ción se inicia en época del obispo don Domingo Jiménez (1285-1328), iniciando los trabajos en la Catedral Vieja el maestro Remondo, siendo continuada en 1328 por los arquitectos Diego Díaz, Juan Pérez y Juan Francés ${ }^{78}$.

Esta fachada está constituida por un arco de medio punto abocinado, con arquivoltas que se apoyan en diez columnas pequeñas rematadas por capiteles decorados con motivos vegetales, semejantes a los capiteles de la parte del Evangelio, salvo uno en el que se ve a una figura humana encapuchada, y otro con dos aves afrontadas y unidas por el pico. Los quicios de la puerta también están tallados, con cuatro seres humanos enfrentados, un personaje agachado con las manos muy enlazadas por delante de las rodillas, y cuatro rostros humanos unidos dos a dos por el occipital. También están decorados los extremos de las jambas con bajorrelieves de figuras humanas muy perdidas. Por encima del arco de ingreso al templo corre un arco, rebajado y poco resaltado, que decora su intradós con elementos vegetales. Pero, las dos imágenes que más nos interesan en nuestro estudio son las que forman el grupo de la Anunciación, con la presencia del Arcángel Gabriel que trae la Buena Nueva a María; es preciso decir que estas escenas de La Salutación se colocaban en el arco de entrada de las basílicas bizantinas. Estas efigies, como el resto de elementos decorativos de la fachada, se encuentran en lamentable estado de conservación, víctimas de las inclemencias del tiempo, al estar expuestas a la intemperie. Ambas imágenes están ejecutadas en granito, son de grandes dimensiones (lo que nos imposibilita el poder medirlas). María está de pie, ha sido sorprendida por el Arcángel leyendo el libro de las Sagradas Escrituras ${ }^{79}$. Ntra. Sra. viste túnica y manto con pliegues que caen elegantes, se ciñe con un cinturón y ostenta un escote redondo muy ajustado al cuello, un rasgo más de antigüedad. Cubre su cabeza con un velo, símbolo de la sabiduría, dejándonos ver los cabellos que se disponen con abundantes rizos. El Arcángel está de pie, dirigiéndose a la Virgen. Lleva en sus manos un pliego enrollado en donde se lee el divino mensaje. Viste túnica talar ceñida al cuerpo por un cíngulo, cayendo los pliegues angulosos y pesados hacia los pies. Los rostros de ambas figuras son muy bellos, el artista estaba ya inmerso en la nueva corriente naturalista que ya se comenzaba a perfilar en el estilo protogótico.

Podemos fechar estas figuras en la primera década del siglo XIV. En la zona superior de la fachada del Perdón, en un lugar muy elevado, podemos apreciar una imagen de la Virgen con el Niño y, delante de ella, un personaje arrodillado ${ }^{80}$. Las esculturas están integradas en el muro de la fábrica y se apoyan en dos ménsulas. Es posible, que se ejecutaran a mediados del siglo XIV.

\footnotetext{
78 BENAVIDES CHECA, J.: op. cit., pág. 47.

79 Según la doctrina de los Padres de la Iglesia, en el momento de la llegada del Ángel la Señora meditaba las profecías de Isaías, el llamado protoevangelista por sus anticipadores virginales y pasionistas. GARCíA MOGOLLON, op. cit., pág. 127.

80 Mélida cree que el personaje arrodillado es el rey Alfonso VIII. MÉLIDA ALINARI: op. cit., pág. 274.
} 


\section{Q: artículos José Antonio Ramos Rubio}
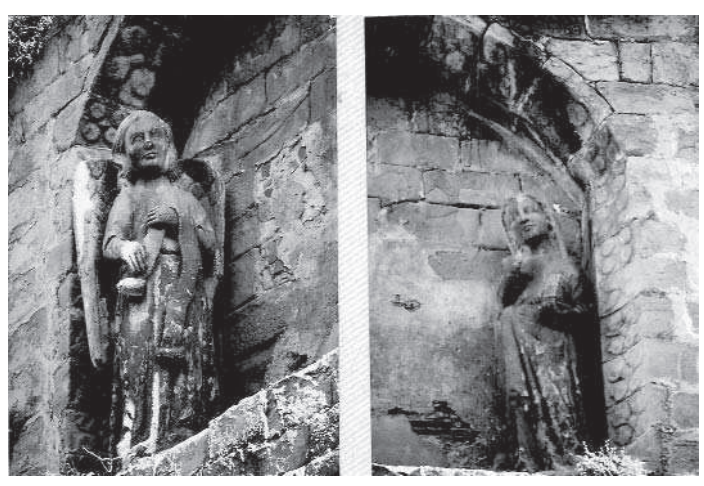

8. Imágenes en la fachada del Perdón (Catedral de Plasencia).

8b. Imágenes en la fachada del Perdón (Catedral de Plasencia).

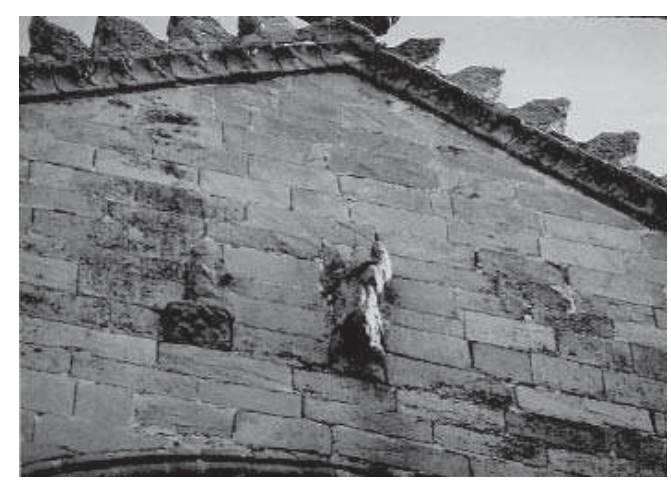

9. VIRGEN CON NIÑO.

En la colección privada Pérez Enciso de Plasencia, se conserva una Virgen con Niño, en madera policromada y estofada. Presenta el tipo de Virgen "Odegetria" bizantina (mide $47 \times 26$ × $17 \mathrm{cms}$.), llevando al Niño $(41 \mathrm{cms})$ en el brazo izquierdo. Está muy deteriorada, le falta a Ntra. Sra. el brazo derecho, posiblemente llevaba en él la fruta esférica. El Niño lleva entre sus manos la bola del mundo. Los pliegues naturalistas de sus túnicas, los rizos que caen sueltos enmarcando el rostro ovalado de Ntra. Sra., y la postura del Niño, desplazado del centro de la composición y vuelto de perfil, nos inducen a datar la obra en el último tercio del siglo XV, estableciendo una relación afectiva entre Madre e Hijo. 


\section{Q: artículos La Mariología en el arte medieval...}

\section{Ntra. Sra. del Puerto.}

En la ermita de la Virgen del Puerto, situada a $5 \mathrm{Km}$. de la ciudad, en la dehesa "Valcorchero" 81 , es muy venerada por todos los placentinos y vecinos de localidades cercanas, una imagen de Ntra. Sra. (1`02 x 55 × $43 \mathrm{cms}$.) con el Niño (38 cms), bajo la advocación de la Virgen del Puerto ${ }^{82}$, que a su vez es la celestial Patrona de Plasencia ${ }^{83}$, declarada por el Papa San Pío X. Por tanto, este ha sido siempre su primitivo emplazamiento. La ermita estuvo a cargo de los franciscanos y, en 1570, pasó a la jurisdicción del obispo ${ }^{84}$. La actual ermita es obra en su mayor parte acometida en los siglos XVII ${ }^{85}$ y XVIII ${ }^{86}$, posiblemente, durante esta última centuria se construiría el camarín de la Virgen. Todo el nuevo edificio, se alzaría a partir de un pequeño eremitorio, obra de la segunda mitad del siglo XV y que sustituyó a un pequeño templo precedente ${ }^{87}$. Las fiestas en honor a la Patrona de Plasencia, se celebran en este santuario el domingo siguiente a la Pascua de Resurrección.

Según relata una venerable tradición la Virgen se apareció a un pastor en lo alto de un cancho, cerca del sitio donde está enclavada la ermita. De ahí el apelativo popular con el que denominan los placentinos a su Patrona: "La Canchalera". La leyenda es muy parecida a otras medievales. Podemos decir, que esta imagen fue

81 En el puerto (de aquí su nombre) de Extremadura a Castilla.

82 Aparece mencionada por primera vez, ya en el año 1509. En el testamento de don Diego de Xerez, deán de la S.I. Catedral de Plasencia, otorgado el 18 de septiembre de 1509. También hace referencias a Ntra. Sra. del Perdón, San Pablo y a las ermitas de Fuentidueñas, S. Cristóbal y S. Lázaro. BENAVIDES CHECA: op. cit., pág. 17. El 6 de diciembre de 1502 falleció don Diego de Lobera, Chantre de la S.I.C., fundador de la ermita del Puerto, en 1480. Fue sepultado en el crucero de la Catedral, sus testamentarios fueron el Sr. Obispo don Gutiérrez Alvarez de Toledo y, curiosamente, el Deán don Diego de Xerez. Ibídem, pág. 18.

83 El médico Luis de Toro, menciona ya esta ermita en su manuscrito del año 1573: "En la cima del monte que mira a la ciudad hacia el septentrión, a unas tres millas de distancia, hay una capilla de la Santa Madre de Dios, ciertamente pequeña, pero hermosa, con una casa aneja y algunos huertos... La ermita se hallaba a cargo de los franciscanos y, en 1570, pasó a la jurisdicción del obispo..." LUIS DE TORO: Descripción de la ciudad y obispado de Plasencia. Plasencia, Ed. de Sayans Castaños, 1961, pág. 35. También, encontramos referencias a esta ermita en FERNÁNDEZ, Fr. A.: op. cit., pág. 18.

84 Como hemos podido constatar en el manuscrito que Luis de Toro escribió en 1573, op. cit., págs. 35 y ss. 85 Existen noticias documentales en las que consta que el santuario estaba terminado en el año 1644 GARCÍA VIDAL, C. (et. al): op cit, pág. 106. Además, hay una lápida que se conserva en la ermita en la que se puede leer: "A gloria y honra de Dios y de su Madre Santísima se hizo este santuario y obra de las limosnas de sus devotos, por no tener renta, ni patrono, siendo obispo de Plasencia el ilustrísimo señor don Diego de Arce, del Consejo de Su Majestad; siendo mayordomo de Nuestra Señora del Puerto Juan Gutiérrez, canónigo, natural de la villa de Béjar, acabóse el año de 1644".

86 Según una inscripción que dice así: "Ejecutóse la nueva fábrica de este santuario a expensas de las limosnas de los devotos, siendo obispo de esta ciudad el ilustrísimo señor don fray Francisco Laso de la Vega: corregidor superintendente, don Juan Francisco de Luján y Arce, mayordomo de Nuestra Señora, don Manuel de Melo, canónigo de esta santa iglesia y capellán de este santuario, don Antonio Cordobés, año de 1723".

87 La ermita del Puerto la fundó don Diego de Lobera en 1480, como ya hemos comentado. Este falleció el 16-XII-1502, quedando dispuesto en su testamento nuevas ampliaciones y obras en la Catedral y en el Palacio Episcopal. BENAVIDES CHECA, J.: op. cit., págs. 18 y 50. BARRIO Y RUFO, J. M ${ }^{a}$.: Historia de la Virgen del Puerto. Zaragoza, Ed. de Fernández Serrano y Sánchez Paredes (según la ed. original de 1854), 1952, pág. 15 


\section{Q: artículos José Antonio Ramos Rubio}

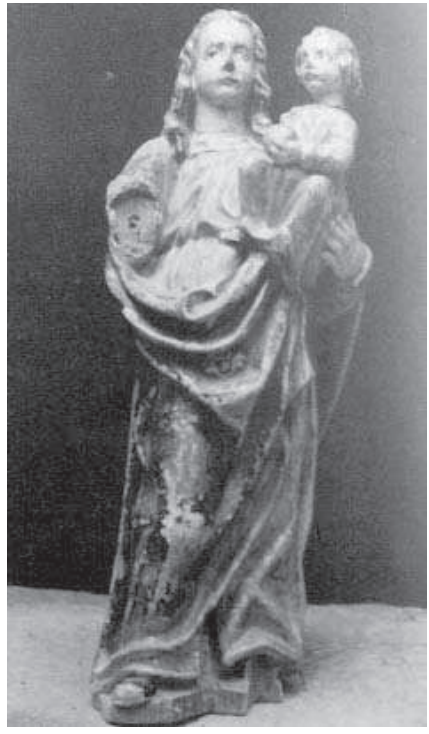

9. Virgen con Niño.

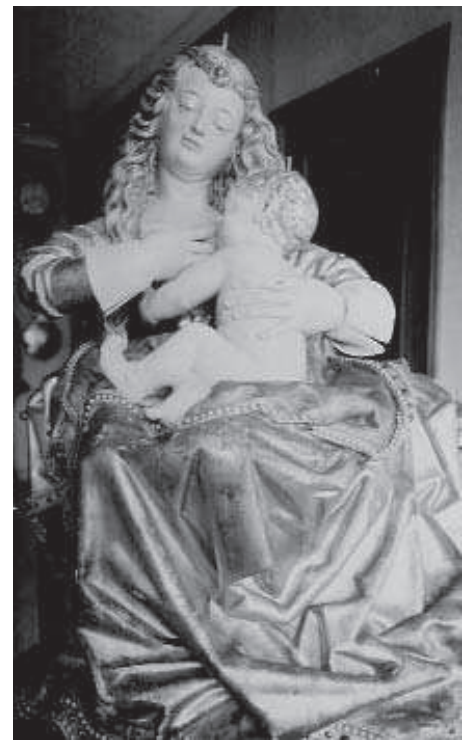

10. Ntra. Sra. del Puerto.

ejecutada entre los años 1480-1485, ya que por estos años don Diego de Lobera ${ }^{88}$, Chantre de la Catedral placentina, fundó la ermita de Ntra. Sra. del Puerto ${ }^{89}$. La imagen que en la actualidad es venerada como Patrona de Plasencia, la Virgen del Puerto, es obra de madera policromada. María está sentada en un trono de madera y sostiene al Niño en el regazo a la vez, que de formas muy naturalistas, le ofrece el seno para que el Infante pueda tomar la leche materna ${ }^{90}$. La Virgen viste ropajes túnica plateada y manto dorado- muy ampulosos, observándose las violentas "angulaciones” del gótico hispano-flamenco, del último cuarto del siglo XV. Lleva túnica plateada y manto dorado adornado con perlas y cabujones de piedras. La policromía no debe ser la original, la actual parece corresponder a la época barroca. El bello y

88 Para conocer datos sobre su vida, se puede consultar el artículo: "Don Diego de Lobera". Hoja informativa pro coronación de la Stma. Virgen del Puerto, núm. 2. Plasencia, 1951 (Anónimo).

$89 \mathrm{El}$ testamento otorgado con anterioridad al 16 de diciembre de 1502, fecha de su muerte, por don Diego de Lobera, es de fundamental importancia para la determinación histórica de la Virgen del Puerto. Archivo de la Catedral de Plasencia.

90 Iconografía de origen bizantino que considera el acto más trascendental de su realeza el dar el pecho al fruto de sus entrañas. Este tipo de Galactotrofousa, toma su mayor apogeo en la época ojival. TRENS, M.: op. cit., págs. 466 y 467. 
risueño rostro ovalado de Ntra. Sra. está enmarcado por abundantes cabellos dorados que caen sueltos por la espalda y hombros. Sostiene delicadamente al Niño, que está completamente desnudo, y adopta una postura muy naturalista, girándose hacia su derecha y cruzando las piernas, indicativo de una época y un estilo que se caracterizó por la dulzura en las representaciones marianas.

Tal es la devoción a su excelsa Patrona, que los placentinos, por obra del primer Marqués de Vadillo ${ }^{91}$, levantaron un santuario en el siglo XVIII a Santa María del Puerto en la capital de España, a orillas del Manzanares ${ }^{92}$. Además, existen varias réplicas de la Virgen del Puerto repartidas por las diócesis de Plasencia y Coria-Cáceres, podemos citar las efigies de Ntra. Sra. de Peñas Albas (Cabezuela del Valle), Ntra. Sra. de la iglesia de San Andrés (Guijo de Granadilla), Virgen de la Leche (ermita Ntra. Sra. de Alta Gracia de Garrovillas), Ntra. Sra. de Aldehuela del Jerte, sin olvidar la Virgen alabastrina de la parroquia placentina del Salvador, entre otras. Ntra. Sra. del Puerto fue coronada canónicamente en el año $1952^{93}$.

Hemos podido seguir, paso a paso, el proceso de restauración llevado a cabo en el Taller de don José Gómez y Gómez, en Trujillo, en el año 1989. La efigie se encontraba en lamentable estado de conservación: agrietamientos en toda la talla con saltados del estuco por cambios bruscos de temperatura; repintes en rozaduras y desgastes; plateados oxidados y desaparecidos por roces; dorado del manto gastado y ennegrecido con señales de golpecitos producidos por cadenas y colgantes.

Durante la restauración, se consolidó toda la talla, rellenando las fisuras para detener los sucesivos saltados con estuco. Se reintegraron las partes saltadas de la imagen y peana con CaSo4-2H20. Proceso de su dorado y plateado al bol con oro y plata finos. Se han protegido de golpes y roces con barnices. La policromía del rostro de Ntra. Sra. y el NIño ha sido retocada, tan solo en sus pequeñas zonas deterioradas.

En el informe enviado al Palacio Episcopal de Plasencia, se advierte: evitar las altas temperaturas por lámparas de alumbrado. En tiempo de verano, si el camarín es caluroso, se debe colocar un recipiente con agua con el fin de proporcionar humedad a la talla. La limpieza del polvo se debe de llevar a cabo con una bayeta suave y, de advertirse algunas grietas en la superficie de su policromía, aplíquese

91 Entre los años 1710-1717, el Marqués de Vadillo, corregidor en Madrid, solicitó datos sobre la Virgen del Puerto al ayuntamiento de Plasencia, fueron recogidos y trasmitidos por don Leonardo Ortiz, regidor perpetuo. Libro de Acuerdos de la Ciudad, 1710-1717. Arch. Municipal de Plasencia. Sobre la biografía de Marqués de Vadillo, se puede consultar al MARQUES DEL SALTILLO: "EI primer marqués del Vadillo (16461729). Rev. del Centro de Estudios Sorianos, V. I, 1951, págs. 189-220.

92 Obra maestra del barroco, realizada por el arquitecto Pedro de Ribera. MARTíN, G.: "Tres advocaciones marianas placentinas". Pregón de las fiestas de la Virgen del Puerto, Madrid 9 de mayo de 1987. Edición en honor de la Stma. Virgen realizada por la Cofradia de Nuestra Señora del Puerto de Madrid, Año Mariano del 7 de junio de 1987 al 15 de agosto de 1988. Imprenta Vimar, Plasencia, 1988, pág. 14. Vid. MARTíN VIZCAÍNO, J.: La Cofradía de la Virgen del Puerto. Madrid, 1973.

93 Vid. JURADO CARRILLO, C.: Memoria histórico-canónica sobre el origen de la coronación de las imágenes de María, condiciones y procedimientos para lograrla y ceremonias que deben preceder, acompañar y seguir a dicha coronación. Lérida, 1912. GONZÁLEZ HERRERO, L.: "Coronación canónica de la Virgen del Puerto, Patrona de Plasencia”. Diario Ya, núm. 4.187, 20-01-1952, pág. 13. 
una buena cera en crema con la bayeta. Por todas estas características expuestas podemos decir que nos encontramos ante una efigie fechable en las postrimerías del siglo XV (hacia 1480), realizada por un escultor anónimo, buen conocedor de la estética flamenquizante que dominaba la Península en los años finales de este siglo. Desde luego, posee la estética, los rasgos artísticos e iconográficos de la Medievalidad, en sus últimos aledaños. A medida que avanza el gótico, se acentúa el realismo en representaciones marianas como ésta, fruto de las ideologías contemporáneas.

\section{Virgen de la Cabeza.}

Es una representación de la Virgen Odegetria -la que guía- bizantina (60 × 40 x $24 \mathrm{cms}$ ). Se conserva en la Escuela-Taller Municipal de Plasencia. Se nos ofrece María en pie, en actitud de caminar, lleva al Niño (35 cms.) sobre el brazo izquierdo. Este, desnudo, juega con su Madre que le ofrece una avecilla, mostrando actitudes naturalistas ${ }^{94}$. Esta imagen de granito que albergaba el templete (granito, $235 \mathrm{cms}$. alto) del "Puente Nuevo" de Plasencia, pudo haber sido realizada por el mismo Rodrigo Alemán autor del mismo o su taller, y dataría de una fecha próxima a la construcción del templete ${ }^{95}$. En 1498, una riada se lleva el antiguo puente de madera conocido con el nombre de "Pascual Clérigo". Al ver la necesidad de él, don Gutiérrez Álvarez de Toledo, obispo de Plasencia, mandó construir uno nuevo, más sólido. Así quedaba asegurado el intenso paso hacia las comarcas de la Vera y el Valle del Jerte. Este nuevo puente data de los primeros años del siglo XVI, es obra de sillería, de estilo gótico, esbelto de proporciones y estrecho de paso. En el pretil del arco central se levantó un hermoso templete gótico que se comenzó en el año 1500 y se terminó doce años después. El templete se compone de tres cuerpos: una hornacina para albergar a la Virgen de la Cabeza y a la que posteriormente se la protegió con una reja; un escudo de los Reyes Católicos; y en la parte inferior, dos escudos con el emblema de la ciudad y una inscripción conmemorativa, en la que reza: "Esta noble ciudad de Plasencia mandó/ hacer este puente de la Ysla regnando/ el rey don Hernando e la reyna doña/ Isabel nuestros señores e comenzose/ En el año del

94 Según TRENS, M: op. cit., págs. 545-547: "Pudiera representar este ave el alma del pescador que escapa al lazo de los cazadores que lo persiguen y encuentra cobijo en brazos de María". También opina, "que al estar la paloma en manos de la Virgen y del Niño, se pone de manifiesto el misterio de la Anunciación de la divina maternidad de María". No obstante, la paloma es asimismo símbolo del Espíritu Santo y por extensión de Cristo Hombre. Por su parte, el Evangelio apócrifo del pseudo Mateo, en el capítulo XXVII (SANTOS OTERO, A. de: Evangelios Apócrifos... op. cit., pág. 225), nos refiere la leyenda de las aves de barro que Jesús fabricó cuando era niño, insuflándolas vida para que volaran.

95 En diciembre del año 1507, ya estaba realizada, según consta en el Libro de Cuentas de propios del Ayuntamiento de Plasencia. Se pagaron "ciento cincuenta y tres maravedís por colocar en la imagen de nuestra. Sra. cerrojos, con sus cerraduras y llaves". Fue pintada en 1509, entre los meses de enero y mayo, por el "pintor valenciano" al que le pagaron doscientos setenta y dos maravedís. Fuente citada. Cuaderno 30.B y $34 . B$. 
señor MCCCCC/E acabose en el de MCCCCCXII a seis del mes de abril/ Fue maestro Rodrigo Alemán"96.

Debido a la intensa circulación que el puente soporta, el templete se vio enseguida seriamente dañado y ya fue objeto de una primera restauración en el año 1897, por don Cesareo, a expensas del Chantre de la Catedral don José Benavides ${ }^{97}$. Originariamente, la imagen fue algo más esbelta de lo que es ahora, ya que al partirse por el cuello, perdió algunos milímetros por lo que parece algo achaparrada.

El templete recibió en 1987 una segunda restauración por parte de los alumnos de la Escuela-Taller de Plasencia, siguiendo los pasos que ahora exponemos:

a) Traslado de las piezas a los talleres de la Escuela.

b) Limpieza superficial de las piezas originales.

c) Adecuación de las piezas no existentes al estilo general del templete, partiendo de un dibujo detallado de este.

d) Unión de las piezas añadiendo grapas y espigas para una mayor sujeción.

e) Restauración de la Virgen de la Cabeza o "de los gitanos".

f) Confección de la reja que la protege.

Hemos tenido la ocasión de comprobar la restauración de la imagen de la Virgen de la Cabeza en el año 1987, tarea llevada a cabo por doña María Antonia González Luceño y un grupo de alumnos de la Escuela-Taller Municipal de Restauración de Plasencia, bajo la dirección de don Antonio Gómez Blázquez.

La restauración ha sido realizada llevando a cabo el siguiente proceso:

a) Se reconstruyeron los fragmentos que faltaban en la corona, rodilla derecha y uno de los pliegues. al temple.

b) Se le aplicaron los panes de oro y se la preparó para recibir la policromía

c) Se perfilaron los rostros de Madre e Hijo, y se le hizo a la obra un tratamiento protector a base de resina.

En esta imagen de granito se reconstruyeron en primer lugar los fragmentos que faltaban en la corona, rodilla derecha y uno de los pliegues, con resina epoxidice. Después, se preparó la imagen con bol rojo, para recibir los panes de oro. Igualmente, se estucaron las encarnaduras para recibir la policromía. Más tarde, se colorearon la túnica y el manto de la Virgen, así se procedió al estofado de éste -a base de estrellas- en fondo azul. Por último, se perfilaron los rostros y la figura recibió un tratamiento protector a base de resina. Por tanto, podemos datar la ejecución de la Virgen de la Cabeza entre los años 1500-1507. Realizada, posiblemente, en el taller de Rodrigo Alemán.

96 Cit. MATÍAS GIL, A.: op. cit., pág. 172.

97 Su obra Prelados placentinos, editada en 1907, es una inagotable fuente de la historia de Plasencia. 


\section{Q: artículos JoséAntonio Ramos Rubio}

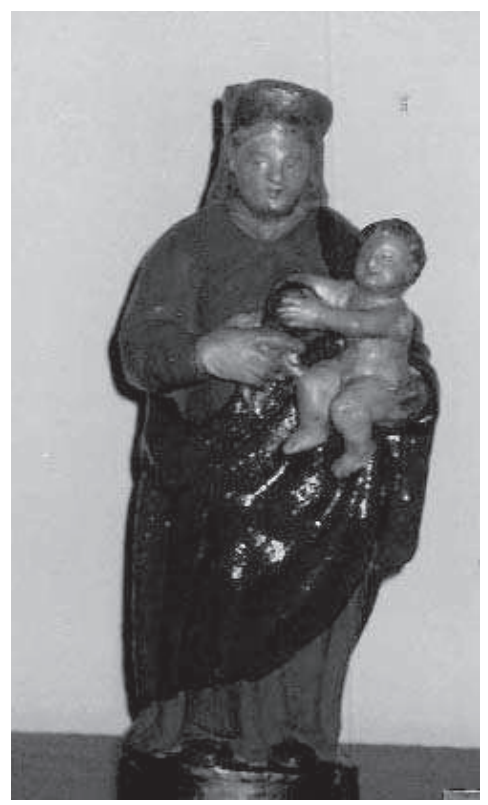

11. Virgen de la Cabeza.

12. VIRGEN CON EL NIÑO.

En el Hospital Psiquiátrico de Plasencia, se conserva una magnífica escultura en alabastro de Ntra. Sra. $(99 \times 50 \times 38)$ con el Niño $(31 \mathrm{cms} \text {. })^{98}$. Procede del antiguo Hospicio, instalado en el siglo XIX en el edificio de la Compañía de Jesús. $\mathrm{Ha}$ sido restaurada recientemente. La obra muestra una clara evolución de los modelos medievales rígidos e hieráticos, para ofrecernos una dulce sonrisa en la Virgen y una comunicación entre la Madre e Hijo, a el cual sostiene delicadamente con sus brazos, dirigida hacia un claro naturalismo, propio de un arte gótico en sus postrimerías. Mientras que el Niño se nos presenta desnudo, María viste amplias y angulosas vestiduras, dejando ver un picudo chapín característico de la indumentaria del siglo XV. El borde del manto está decorado con pedrería. La Virgen lleva grandes mechones peinados hacia atrás y lleva sobre su ovalada cabeza una diadema sencilla. Calza zapatos terminados en punta, frecuentes en obras artísticas de los últimos años del siglo $\mathrm{XV}^{99}$. Figuró en la Exposición: Patrimonio Histórico de Extremadura. Edad

98 TERRÓN REYNOLDS, M. T. y PIZARRO GÓMEZ, F. J.: Catálogo de los fondos pictóricos y escultóricos de la Diputación Provincial de Cáceres. Cáceres, 1989, pág. 272.

99 BERNIS, C.: op. cit. 
Media y Renacimiento, celebrada en Cáceres en el año 1990. Es obra anónima, muy en la línea del gótico francés, fechable en el último tercio del siglo XV.

\section{Ntra. Sra. de la Salud.}

Es en el último cuarto del siglo XII cuando el rey Alfonso VIII, acompañado por las huestes de León y Burgos, conquista la localidad musulmana de Ambroz, entrando en ella por el puente llamado de la "Piedra Vieja" -hoy conocido como Puente de Trujillo- y funda en ella una ciudad que poco después llamaría Plasencia $^{100}$.

Al no existir fuentes escritas nos tenemos que limitar a lo que nos cuenta la tradición: "El rey Alfonso VIII llevaba en su equipaje de campaña una imagen de la Virgen por la que sentía una especial devoción y a cuya intercesión achacaron el éxito de la campaña (se recuperó Plasencia en 1196) ${ }^{101}$, por lo que ordenó se hiciese una copia de la misma y se colocase encima de la puerta de la muralla que habría de construir. Así se hizo, para ser venerada bajo la advocación de Ntra. Sra. del Remedio"102.

La devoción a esta imagen pronto se hizo vigorosa, habilitándose en la misma muralla una pequeña ermita u oratorio. El 14 de junio de 1653, la Virgen del Remedio pasó a denominarse oficialmente Ntra. Sra. de la Salud. La pequeña ermita fue ampliada para que ocupase toda la cimera de la Puerta de Trujillo, flanqueada por dos sacristías que ocupan los dos cubos defensivos de la puerta. Una de estas estancias es la sacristía propiamente dicha y la otra es la llamada "cuarto de los faroles", por guardarse en ella los grandes faroles que sacaban en el rosario matinal diario que celebraba la cofradía de Ntra. Sra., siendo utilizada también, según constan en la documentación de la Devoción, como lugar de alojamiento de peregrinos.

100 Fue Sayans el primero que nos habló sobre la presencia céltica de la población de Ambroz. SAYANS CASTAÑOS: Artes y pueblos primitivos de la Alta Extremadura, op. cit., págs. 243-260. Desde luego, en el Fuero fundacional de Plasencia se dice:"...in loco qui antiquius vocabatur Ambroz urben edifico...". FERNÁNDEZ, Fr. A.: op. cit.; BENAVIDES CHECA, J.: Fuero de Plasencia. Roma, 1896. Pero, "la idea predominante es que, al margen de la preexistente ocupación, mantenida en tiempos de los romanos, Plasencia tiene una auténtica entidad ciudadana como consecuencia de la fundación del monarca Alfonso VIII, que alcanzó su mayor desarrollo en la Baja Edad Media". Cit. ANDRÉS ORDAX, S.: op. cit., pág. 48.

101 Por este motivo se dispuso una inscripción junto al escudo de los RR. Católicos, en la que se expresa la desvinculación señorial de Plasencia para pasar a la autoridad regia, cuya traducción es: "La libertad vale más que la vida, las piedras preciosas y el oro. La libertad está ya devolviendo su nobleza a Plasencia. Derrotada por la Fortuna y redimida para ser esplendor de los Reyes. Por esto los nobles placentinos, héroes en su ciudad, siguiendo las banderas reales, desbarataron a los feroces enemigos, porque sólo es digno de los hombres el estar sometidos a sus reyes. Mes Octubre, año de (insertas las armas de Francisco de Carvajal) 1488". SERRANO, F.: "Una inscripción en Plasencia". Revista de Estudios Extremeños. Badajoz, 1947, págs. 203-207.

102 MARTÍN, G.: "Tres advocaciones marianas placentinas". Ed. en honor de la Stma. Virgen realizada por la Cofradía de Ntra. Sra. del Puerto de Madrid. Pregón de las fiestas de la Virgen del Puerto, Madrid, 1987 (Imprenta Vimar, Plasencia, 1988), pág. 6. Pero, como suele suceder, la tradición no se corresponde con la realidad, ya que la imagen actual que se venera como Virgen de la Salud, es una talla gótica, de los primeros años del siglo XVI, de derivación hispano-flamenca. 


\section{Q: artículos José Antonio Ramos Rubio}

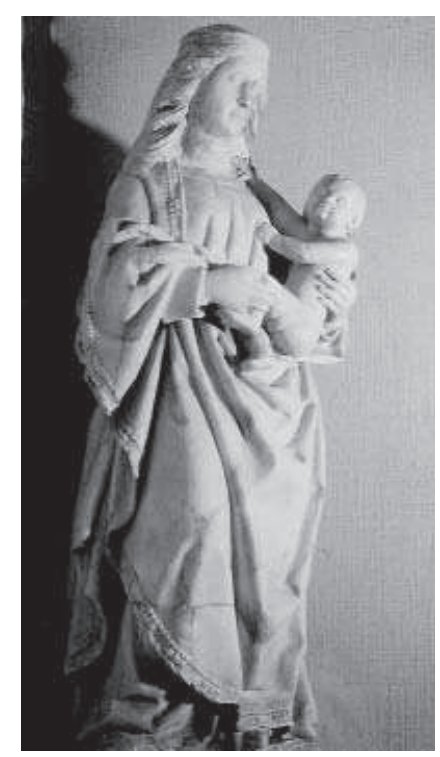

12. Virgen con el Niño.

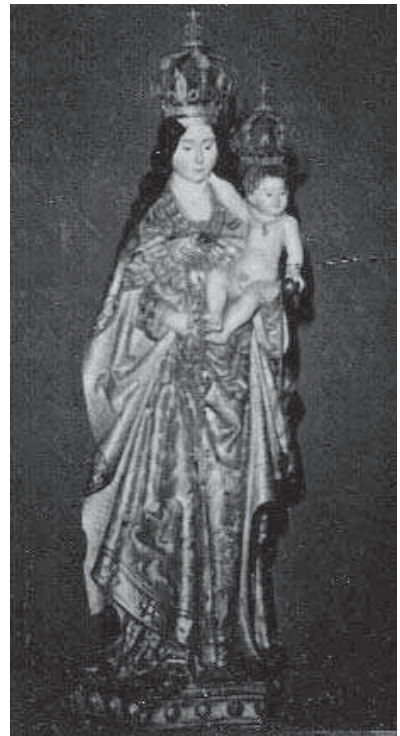

13. Ntra. Sra. de la Salud.

El 5 de abril de 1721 comenzó la construcción de la nueva ermita de la Virgen de la Salud, sobre el arco de la puerta de Trujillo, concluyendo las obras en el año 1723. En la misma época se construyó la ermita de la Virgen del Puerto ${ }^{103}$. El 22 de mayo de 1725 fue entronizada la Virgen en su nuevo santuario, tras permanecer en la Catedral durante el tiempo que duraron las obras ${ }^{104}$.

Al modo de una "Odegetria" bizantina, la Virgen está en pie y sus proporciones son muy esbeltas (103 × $42 \times 28 \mathrm{cms}$.), afilándose a la base como corresponde al período gótico final. Ntra. Sra. sostiene al Niño $(33 \mathrm{cms}$.) con ambas manos, este descansa en el brazo izquierdo de su Madre. El cabello le cae en cascada por la espalda y sobre los hombros, en torno al agradable óvalo del rostro, de una manera flamenquizante, tratamiento usual a finales del siglo $X V^{105}$. El Niño está desnudo y adopta una postura juguetona, cruzándose las piernas con naturalidad delante del regazo de María. Con la diestra se agarra al cuello de su Madre, actitud muy graciosa. El Niño presenta algunos caracteres iconográficos semejantes al Niño que lleva

103 Guía de la ciudad de Plasencia por un placentino. Plasencia, Imprenta Placentina, 1905, pág. 14

104 MARTÍN, G.: "Tres advocaciones marianas placentinas", op. cit., pág. 6.

105 Tallados con unas estrías semejantes a las que ostenta la Virgen de Fuentes Claras, de Valverde de la Vera y Ntra. Sra. de la Piedad, de El Torno. 
entre sus brazos Ntra. Sra. de la Esclarecida, de la parroquia de Santiago de Cáceres (obra del último cuarto del siglo XV). Ntra. Sra. viste túnica y manto muy ricos, dorados y estofados con abundantes motivos geométricos y vegetales que enriquecen la efigie. La túnica de la Virgen María ostenta un característico escote cuadrado que puede fechar la imagen en los últimos años del siglo $\mathrm{XV}^{106}$, escondido tras el lujoso y voluminoso manto, que está abrochado al centro, rasgo característico en la moda de la segunda mitad del siglo XV. El manto cae hacia los pies en acartonados y paralelos pliegues, concebidos con gran elegancia, en donde se notan las violencias "angulaciones" propias del estilo gótico, dejándonos ver los zapatos de punta redonda que calza Ntra. Sra. Además, el cinturón con el que se ciñe la túnica está situado a buena altura en el talle, lo cual también prueba que es una imagen de derivación gótica. Además, la peana hexagonal en la que se apoya la Virgen María está decorada con elementales molduras y "pometeados", semejantes a los que veremos en la peana de Ntra. Sra. de la Piedad (EI Torno), los cuales nos proporcionan un dato clave y de especial relevancia para relacionar la estatura con la etapa hispano-flamenca de finales del siglo XV. Además, la talla propiamente dicha no puede negar su adscripción a modelos de estirpe hispano-flamenca.

Por tanto, consideramos que se trate de una obra realizada por un anónimo maestro, excelente tallista, entre los años 1500-1504, de derivación gótica hispanoflamenca.

106 BERNIS, C.: op. cit., pág. 205. 
